\title{
Network-Based Measures of Systemic Risk in Korea
}

\author{
Jaewon Choi ${ }^{*}$, Jieun Lee**
}

The views expressed herein are those of the authors, and do not necessarily reflect the official views of Bank of Korea. When reporting or citing this paper, the authors' names should always be explicitly stated.

* Associate Professor of Finance, Gies College of Business, University of Illinois/Joint Associate Professor, College of Business, Yonsei University, Tel: +1-217-244-0840, E-mail: jaewchoi@illinois.edu

** Economist, Economic Research Institute, Bank of Korea, Tel: +82-2-759-5470, E-mail: jelee@bok.or.kr

We thank seminar participants at Bank of Korea for useful comments. We also thank Bank of Korea for the financial support. All errors remaining are ours. 


\section{Contents}

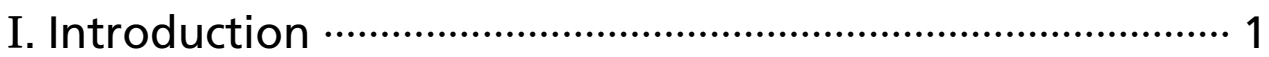

II. Measures of Systemic Risk ……................................. 5

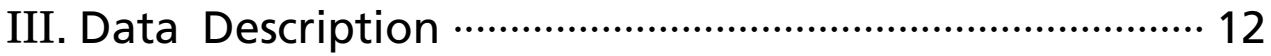

IV. Empirical Results ……................................................... 13

V. Conclusion ….................................................................. 31

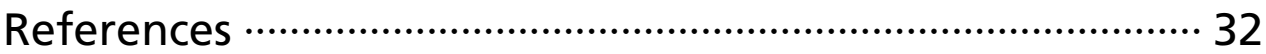




\section{Network-Based Measures of Systemic Risk in Korea}

We estimate systemic risk in the Korean economy using the econometric measures of commonality and connectedness applied to stock returns. To assess potential systemic risk concerns arising from the high concentration of the economy in large business groups and a few export-oriented sectors, we perform three levels of estimation using individual stocks, business groups, and industry returns. Our results show that the measures perform well over our sample period by indicating heightened levels of commonality and interconnectedness during crisis periods. In out-of-sample tests, we show that the measures can predict future losses in the stock market during the crises. We also provide the recent readings of our measures, both at the market, chaebol, and industry levels. The measures indicate systemic risk is currently not a major concern in Korea, as they tend to be at the lowest level since 1998. Systemic risk within-chaebols or within-industries overall has not significantly increased in the recent sub-period. In contrast, commonality within the finance industry has not subsided, which we interpret as capturing the interconnectedness endemic to the finance industry, rather than indicating a heightened systemic risk within the banking sector.

Keywords: Systemic risk, Network analysis, Korean economy

JEL Classification: G11, G14, G23 


\section{Introduction}

How big is systemic risk in the Korean economy and how can we measure it? These are undoubtedly one of the most important questions for policymakers, regulators, and academics alike. The concept of systemic risk stems originally from the banking literature, referring to the risk of a crisis in the banking system. Since the recent financial crisis of 2008, however, systemic risk is applied to a more broader sense, indicating an economy-wide shock that may or may not arise from the financial sector and regulators around the globe are increasingly concerned with assessing and moderating it.

A proper assessment of systemic risk in Korea is particularly an important issue, given the following considerations of the uniqueness of the Korean economy. First, Korea is an export-driven, relatively open economy that is highly vulnerable to shocks from abroad, particularly when the global economy takes a downturn. Any crisis situation that occurs during global economic downturn can pose a great threat to the economic stability of Korea. Second, the Korean economy is highly concentrated in a few large business groups (chaebols) and export-oriented manufacturing sectors (e.g., semiconductors and automobiles). As disproportionately large portion of the economy depends on a relatively fewer sectors and corporations, systemic risk concerns due to a possible collapse of too-big-to-fail corporations are all the more important. As such, a failure of a big industrial corporation can have a substantial ripple effect through the customer-supplier network and also through the banking system. Third, the economic crisis in late 90's - the Asian financial crisis - had everlasting impacts in Korea, not only economically, but also politically and socially, and preventing another crisis is perhaps is one of the most important issues to policymakers.

Measuring systemic risk, however, is not an easy task. As mentioned, systemic risk in a broad sense refers to market-wide risks that are crucial to the overall soundness of the economy. Practically, it is a concept that is elusive to measure. In a narrow sense, one can measure systemic risk 
of a banking system, based on the exposure of the balance sheet of financial institutions to other financial institutions to see how interconnected those institutions are with each other. This approach might not be plausible to assess systemic risk that is not confined to the banking sector, as it is not entirely clear how firms in non-banking sectors are economically interconnected due to the lack of data availability. Thus, when applied in a broader sense, systemic risk is not straightforward to define and also difficult to quantify.

Our goal in this paper is to propose a set of measures for systemic risk to take a first step towards understanding the degree of such risk in the Korean economy (not just in the banking sector). In particular, we focus on the commonality and connectedness of the Korean stock market through the following two econometric methods that are well-suited for our purposes: the principal component analysis (PCA) and the network analysis based on Granger-causality, following Billio, Getmansky, Lo, and Pelizzon (2012). Applying these two econometric methods, we exploit the unique feature of the Korean stock market, that is, high concentration of economic power in both large chaebols and major export industries. Specifically, we examine the systemic risk of the stock market at the market, chaebol, and industry levels by investigating returns on the largest 50 stocks, 30 chaebols, and major industries, respectively. Note that we employ market prices to estimate systemic risk, instead of employing balance sheet data. By exploiting market data that are by construction forward-looking, our measures have advantages in that they can detect changes in risk levels much quicker than backward-looking balance-sheet based measures.

The two econometric methods are particularly well designed to measure the commonality and connectedness of the stock market, which are arguably key characteristics of systemic risk. According to Reinhart and Rogoff (2009), linkage in the system is one of the four major elements (the four "L"s) of crises. Linkages among stocks will show up as commonality and connectedness in the stock market. In this regard, the PCA allows us to estimate the number of important common factors and thus can measure how important commonality in stock 
returns is over time. The Granger-causality network analysis measures will illuminate the complex network structure of the Korean stock market and thus allows us to identify the network structure and potential spillover and interconnectedness of the system.

Our results show that the systemic risk measures do a very good job in capturing system-wide risk in the stock market for our sample period from 1994 through 2018. The measures of commonality and connectedness in the system increase substantially during the past two crisis periods, that is, the Asian financial crisis and the 2008 financial crisis periods. In contrast, the systemic risk measure points to subsided levels of commonality and connectedness during post-crisis periods. Among the 50 largest stocks, for example, the fraction of linkages in the stock market peaks to $25 \%$ during the Asian crisis period, indicating one in four stocks are interlinked with one another, but it decreases to less than $5 \%$ in mid 2000s. We also find that systemic risk in the Korean stock market has never reached the same level as in the Asian financial crisis, although it increases during the financial crisis period. For example, the fraction of linkages again increases to over $7 \%$ during the 2008 crisis, but compared to the late 90 's, it is at a modest level, indicating that our systemic risk measures are likely to capture the risk from the insolvency of the corporate sector (i.e., Asian financial crisis) well rather than the risk from the collapse of the financial sector (i.e., the 2008 financial crisis).

We also find that these systemic risk measures have out-of-sample predictive power for future losses in the stock market. At the onset of the two crises, the network connectedness measures predict higher losses in the cross section of the largest 50 stocks. That is, the more connected a stock is with other stocks as measured by Granger-causality networks, we find bigger losses for the stock. Overall, these results show that our commonality and connectedness measures can be a useful tool for detecting systemic risk in the market.

We also examine the extent to which our measures signal cautions regarding increased systemic risk in the stock market. Overall, we find that 
the level of connectedness and commonality is at the lowest levels since early 2000. The largest principal component does not explain more than $20 \%$ of system-wide variance, while it used to explain more than $40 \%$ until mid 2010s. Although there is some evidence that interconnectedness is increasing in 2018, it does not show a strong trend. The other network measures also point to similar conclusion that systemic concern is not particularly high in the recent period, compared with prior to early 2010 .

We further examine systemic risk in Korea, focusing on the recent periods. In particular, we search for any noticeable increases in commonality and interconnectedness within four major chaebols as well as the major industries including electronics, automobile, and finance. Any build-up in systemic risk in these business groups and industries can have a large impact on the Korean economy, as it is heavily dependent on the economic soundness in them. In our within-chaebol analysis, we do not find a substantial increase in systemic risk, although some chaebols exhibit some increasing trend in both commonality and connectedness, perhaps due to their heavy dependence on the major member firms. In our industry-level analyses, we do not find a significant increase in commonality and connectedness in any of the three industries. However, the finance sector exhibits a relatively high level of commonality and connectedness throughout the period after 2010. Such a trend of systemic risk can be explained by the features of the financial institutions where they trade frequently with each other.

This paper contributes the literature on measuring systemic risk by extending the measures proposed in Billio et al. (2012). For example, Adrian and Brunnermeier (2016) propose CoVaR, which measures the change in value at risk of the financial system. Brownlees and Engle (2016) introduce SRISK that focuses on the contribution of a financial firm on systemic risk. Acharya et al. (2017) use SES, which measures the expected loss of a financial firm in case of financial market crisis. Huang, Zhou, and Zhu (2012) suggest DIP that estimate the marginal contribution of the financial firms to distress insurance premium of the financial system. Our paper also contributes to the 
literature that measures the systemic risk of Korea, e.g., Lee (2015) and Seo (2014).

\section{Measures of Systemic Risk}

In this section, we provide two broad categories of commonality and connectedness measures that can represent the correlation and causality structure of the Korean stock market, which we argue can measure the systemic risk of Korea. The first type of measures is based on the PCA of the major stocks in Korea. The measure allows us to quantify the extent to which the largest components of common risk in stock returns explain account for the variance of the system. The main idea of the measure is that, when the systemic risk in the market is high, a larger portion of stock market risk should be driven by the common component. The second type of measures is based on the Granger-causality network analysis and thus enables us to assign directions of common risk among stocks. That is, we estimate pairwise Granger-causality among stock returns to model the network structure of Korean stock market among major companies.

\section{Measuring Systemic Risk in the Korean Setting}

Before we explain in greater detail how we measure systemic risk, we first provide a more formal discussion of the definition of systemic risk. Note that there is no accepted definition of systemic risk. Perhaps, the quote of U.S. Supreme Court Justice Potter Stewart's regarding pornography might describe it the best: "I know it when I see it." In other words, systemic risk is difficult to define in a formal way, but many academics, policymakers, and regulators alike have been using the term as if they know it when they see it.

For the purpose of our paper, however, such an informal, intuitive discussion of the true nature of systemic risk is not particularly helpful as we aim to provide measures of such risk so that they can be helpful in 
practice. Although the concept of systemic risk originally stems from the banking literature1), after the onset of the 2008 financial crisis, it generally refers to the following in a broader sense, not confined to the banking risk: any set of circumstances that threatens the stability of or public confidence in the financial system and also the entire economy. ${ }^{2)}$ In the U.S. finance literature, systemic risk is mainly confined to the risk in the financial system, as its importance increased after the recent financial crisis, which was a major threat to the financial system.

Considering the unique characteristics of the Korean economy, the concept of systemic risk should be more generally applied to the economy, or to the manufacturing sector, not just to the finance sector. This is because the Korean economy is highly concentrated in the export-oriented manufacturing sector, for example, semiconductor, shipbuilding, automobile, and steel industries, and also in a few large business groups that dominate the economy. A crisis in these manufacturing sectors or chaebols can easily spread into the banking sector, as Korean manufacturing firms are heavily dependent on bank financing rather than public equity and debt financing. A good example is the currency and economic crisis in the late 90s, during which period the crisis in the manufacturing sectors due to high debt burdens, combined with decreased profitability, spilled over to the banking sector, as

1) Several survey papers on systemic risk in banking have summarized the details on various issues (i.e., systemic risk-taking, contagion and amplification and bank runs). See Borio and Drehmann (2009) and Kaufman and Scott (2003) for the definitions and Benoit, Colliard, Hurlin, and Pérignon (2017) for the more recent papers. Recently, Adrian and Brunnermeier (2016) and Acharaya et al. (2017) define system risk based on bank tail risk and the connection of the bank with the system in financial distress.

2) See also De Bandt and Hartmann's (2000) review of the systemic risk literature, which provides the following alternative view:

"A systemic crisis can be defined as a systemic event that affects a considerable number of financial institutions or markets in a strong sense, thereby severely impairing the general well-functioning of the financial system. While the "special" character of banks plays a major role, we stress that systemic risk goes beyond the traditional view of single banks'vulnerability to depositor runs. At the heart of the concept is the notion of "contagion," a particularly strong propagation of failures from one institution, market or system to another.

In a similar vein, Daniel Tarullo, the former Federal Reserve Governor, mention that "A systemic risks is defined as the potential for an event or shock triggering a loss of economic value or confidence in a substantial portion of the financial system, with resulting major adverse effects on the real economy." Modernizing Bank Supervision and Regulation Testimony before the Committee on Banking, Housing, and Urban Affairs, US Senate, Washington, DC, 19 March, 2009. 
major banks in Korea had very concentrated loan portfolios to the large business groups, which also can create the too-big-to-fail phenomenon and push the entire Korean economy to the crisis. For these reasons, it makes more sense to examine the risk of the system, including the manufacturing sectors as well, to better measure the real threat to the Korean economy. While these considerations that are unique to Korea make it more appealing to apply the concept of the systemic risk more broadly to the entire economy, it is still unclear how to measure the systemic risk of the economy, or risk to the stability and public confidence of the economy, according to the formal definition discussed above. After all, how can we measure stability and public confidence? We refer to Reinhart and Rogoff's (2009) narrative of economic and financial crises in this regard, that is, the four "L"s that characterizes crises: leverage, liquidity, losses, and linkages. The literature on the financial crises already provides a long list of studies for the former three. ${ }^{3)}$ However, another defining characteristic of the Korean economy is tight linkage in the large business groups, that is, the connections and interactions among the member firms in the business groups. In this regard, a systemic risk measure that can capture the connections and linkages among firms is highly important. Thus, the main emphasis of our paper is on how to measure the linkages, that is, the fourth "L" of Reinhart and Rogoff (2009).

Among the recent literature that covers the measurement issue of U.S. systemic risk4), it is rather well-established that systemic risk events are associated with the common holdings (and their return correlations) in financial institutions, how concentrated the risk of the financial system is, and how

3) Among many others, see, for example, Amihud and Mendelson (1986), Brennan, Chordia, and Subrahmanyam (1998), Chordia, Roll, and Subrahmanyam (2000, 2001, 2002), Glosten and Harris (1988), Lillo, Farmer, and Mantegna (2003), Lo, Mamaysky, and Wang (2001), Lo and Wang (2000), Pastor and Stambaugh (2003), Sadka (2006), Lo (2001), Getmansky, Lo, and Makarov (2004), Billio, Getmansky, and Pelizzon (2011), and Acharya, Pedersen, Philippon, and Richardson (2017).

4) A variety of systemic risk measures has been proposed in the wake of the 2008 global financial crisis. Bisias et al. (2012) and Benoit, Colliard, Hurlin, and Pérignon (2017) provide comprehensive survey papers regarding systemic risk in banking and financial institutions covering more than 40 systemic risk measures and they highlight that no single measures can be used as the proxy of systemic risk that can fully detect crises. 
cross-linked the financial institutions are with one another. In this line of research, for example, there are already quite a few studies proposing measures of systemic risk.5) Although these existing measures have broadened our understanding of systemic risk, their main shortfall is that it is ex-post. That is, they can capture systemic risk exposures only after they show up in data, as these measures mainly focus on the loss components of systemic risk. It would be too late from the point of view of regulators and policymakers, once systemic losses are realized.

In this paper, we take a rather different approach, following the work of Billio et al. (2012), who measure the correlation structure of the major financial institutions in the U.S. such as banks, hedge funds, and insurance companies. Their approach is to measure the correlation structure through PCAs and the Granger-causality tests, with which they estimate how deeply connected the financial system is. For example, it is possible that in good times average correlation declines, but in certain sectors, or in certain business groups, connectedness can increase, which can signal increased systemic risk to the economy. Thus, by examining the snapshots of the network linkages and connectedness, we can assess how vulnerable the Korean economy would be given unexpected shocks from the outside.

Based on the discussion above, we examine the network structure, as measured using the principal component analysis and the Granger-causality tests and the extent to which the measures of the network linkages in the Korean stock market can predict losses in the stock market. In the next subsections, we provide a greater detail of our measures.

\section{Principal Component Analysis}

A heightened level of systemic risk leads to increased principal components, as stock returns of major companies should commove more strongly. We measure this increase in commovement in stock returns, using

5) For example, Adrian and Brunnermeier (2016), Acharya, Pedersen, Philippon, and Richardson (2017) and Huang, Zhou, and Zhu (2012), among many others. 
the principal component analysis. Just as a brief review, we provide the basic PCA procedure here. Let $R^{I}$ be the stock return of firm $I, I=1, \cdots, N$, and the variance-covariance matrix of the stock returns is $\sum$. We use standardized stock returns to make sure that any single stock return with huge variance do not account for the largest component. Let $\lambda_{k}$ be the k'th largest eigenvalue and $a_{k}$ be the corresponding eigenvector of the variance-covariance matrix. Then, the k'th principal component is given as $Y_{k}=a^{\prime}{ }_{k} R$ where $R$ is the column vector of stock returns. The eigenvalue $\lambda_{k}$ provides the variance of the k'th principal component.

The PCA decomposes the variance-covariance matrix of the Korean stock market into a linear combination of stock returns that represent the maximal variation of the system. It is generally the case that the first few components explain the vast majority of the variation in the system. In particular, during the crisis period, the majority of stock returns tend to commove and the first few principal components account for the largest variation of stock returns in the system. In this sense, the PCA captures the connectedness of the stock market.

\section{Network Measures Based on Granger-Causality}

Although the PCA presented above can explain time-variation in comovement of stock returns, it does not consider the propagation of shocks in the system. To address this issue, we use Granger-causality of stock returns and measure the directionality of links between stock returns.

Let $R_{t}^{i}$ and $R_{t}^{j}$ be stock returns for firm $i$ and $j$. We have a system of two data generating processes to represent Granger-causality in the system:

$$
\begin{aligned}
& R_{t+1}^{i}=a^{i} R_{t}^{i}+b^{i j} R_{t}^{j}+e_{t+1}^{i}, \\
& R_{t+1}^{j}=a^{j} R_{t}^{j}+b^{j i} R_{t}^{i}+e_{t+1}^{j},
\end{aligned}
$$

where $e_{t+1}^{i}$ and $e_{t+1}^{j}$ are two error series that are not correlated with each other. Then, Granger-causality is defined as $j$ Granger-causes $i$ when $b^{i j}$ is 
different from zero. Likewise, $i$ Granger-causes $j$ when $b^{j i}$ is non-zero. Note that Granger-causality does not suggest any causal relationship between the two variables. Rather, it should be interpreted in a statistical sense.

In a frictionless, efficient market, one should not expect to see any Granger-causality links in the stock market. This is because all the pieces of information in the market should be reflected in stock prices immediately. However, there are plenty of reasons for why one would expect Granger-causal links in stock markets. Market frictions, for example, short sale constraints, borrowing and margin constraints, and any costs associated with information acquisition including limited attention of investors will preclude immediate response of stock returns to information. Therefore, any spillover effect amongst firms that arises from any underlying economic links between firms, e.g., supplier-customer relationship, will show up as Granger-causality in stock return data. In other words, the degree of Granger-causal links in stock returns can be treated as a measure of spillover effects, financial or economic, among firms, as suggested by Danielsson, Shin, and Zigrand (2011), Battiston, Delli Gatti, Gallegati, Greenwald, and Stiglitz (2012), and Buraschi, Porchia, and Trojani (2010). The Granger-causal links can amplify when they form a highly connected network, which is also shown by Castiglionesi, Feriozzi, and Lorenzoni (2009) and Battiston, Delli Gatti, Gallegati, Greenwald, and Stiglitz (2012). Based the arguments of these studies, we use the Granger-causality measure of connectedness to model the spillover effects in a stock market network in Korea.

We define the following notations of causality:

$(j \rightarrow i)=1$ if $j$ Granger-causes $i$, and $(j \rightarrow i)=0$ otherwise.

and $(j \rightarrow j)=0$. Using these indicator variables, we characterize the network structure of the stock market. Specifically, we define the following measures as in Billio et al. (2012):

Degree of Granger-causality (DGC) is the fraction of statistically significant Granger-causal links among all combinations of total of $N$ stocks. Note that DGC is defined for the entire network unlike the other measures defined for each node. Specifically, DGC is given as 


$$
D G C \equiv \frac{1}{N(N-1)} \sum_{i}^{N} \sum_{j \neq i}(j \rightarrow i)
$$

The number of in and out connections counts the number of directional Granger-causal links for in and out links, separately. $S$ denotes the entire stock market (composed of the major stocks).

$$
\begin{gathered}
\text { \# Out }:(j \rightarrow S)=\frac{1}{N-1} \sum_{i \neq j}(j \rightarrow i) \\
\text { \# In }:(S \rightarrow j)=\frac{1}{N-1} \sum_{i \neq j}(i \rightarrow j) \\
\text { \# In+Out }:(j \leftrightarrow S)=\frac{1}{2(N-1)} \sum_{i \neq j}(i \rightarrow j)+(j \rightarrow i)
\end{gathered}
$$

Closeness represents how close a firm is from all the other firms in the stock market. The first step is to calculate a monthly causal link from a stock $j$ to $i$ through all possible paths: $\left(j \rightarrow k_{1}\right) \times\left(k_{1} \rightarrow k_{2}\right) \times \ldots \times\left(k_{n} \rightarrow i\right) \equiv(j \rightarrow \rightarrow i)$ $=1$. Then we denote using $C_{j i}$ the distance of the shortest weak causal link from $j$ to $i: C_{j i} \equiv \min \{C \in[1, N-1]:(j \rightarrow \rightarrow i)=1\}$. The closeness measure is defined as

$$
C_{j S}=\frac{1}{N-1} \Sigma_{-}(i \neq j) C_{j i}(j \rightarrow \rightarrow i)
$$

Eigenvector centrality is a popular measure in network theory by calculating the average centrality measures surrounding a stock. The first step is to define the adjacency matrix $A$ whose element is $[A]_{j i}=(j \rightarrow i)$. The centrality measure is the eigenvector $v$ of the adjacency matrix. Among many eigenvectors, we choose the one whose eigenvalue is one:

$$
A v=v
$$

Intuitively, this measure is the average of all the centralities around a node. 


\section{Data Description}

Our focus is to examine systemic risk in the Korean economy, exploiting common movement and lead-lag relationship in stock returns rather than employing balance sheet information over the period from 1994 through 2018. We obtain monthly stock returns and the number of outstanding shares from FnGuide6), corporate bond yields, 5-year government bond yields and CD rates from Kofiabond7), and financial stability index from BOK.8) The choice of this data frequency and also the sample period serve our purpose well. First, we work with monthly data instead of higher frequency data, i.e., weekly or daily, because of the tradeoff between microstructure issues and statistical power. On one hand, our statistical estimation can have stronger power if we employ higher frequency data. On the other hand, because of potential nonsynchronous trading in relatively smaller-sized stocks, estimation can be noisier with higher frequency returns, which will lead to overestimation of connectedness and underestimation of commonality (Scholes and Williams, 1977). To balance between statistical power and noise due to microstructure issues, we use monthly frequency data. Second, our sample period from 1994 through 2018 covers the major systemic crisis periods of Korea, namely, the late 90s Asian financial crisis, the 2008 financial crisis, and the recent stagnation in economic growth in late 2010s, thus allowing us to compare the performance of the systemic risk measures throughout the sample period.

In our main empirical analyses, we investigate systemic risk at the following levels: the stock market level9), using the largest 5010) or 36 stocks; the business group level, using the largest 30 business groups; and the sector level, using the industry classification from the Korean stock exchange (KRX). To examine

6) FnGuide is a local data provider similar to CRSP.

7) http://kofiabond.or.kr.

8) Financial stability index is obtained from the Financial Stability Report (2018), published by Bank of Korea.

9) We measure size based on the market capitalization, multiplying the current stock price (closing price) by the number of total outstanding shares.

10) At the end of 2018 , the top 50 firms account for $58.54 \%$ of the total market capitalization in the KRX. 
systemic risk at the business group and sector level, we also construct aggregate stock returns at the business group and sector levels, respectively, by value-weighting individual stock returns in the groups or sectors. As alternative proxies of systemic risks, we use credit spread, term spread and financial stability index: the credit spread is computed by the difference in BBB and AA corporate bond yields in Korea; the term spread is the difference between 5-year government bond yields and 3-month CD rates in Korea.

\section{Empirical Results}

In Section 4.1, we first implement the connectedness and commonality measures introduced in the previous section. We estimate commonality using the PCA and connectedness using the Granger-causality network analysis, focusing particularly on the graphical illustration of how the measures change before and after the major crises in the Korean economy. In Section 4.2, we perform out-of-sample predictive regressions of maximal realized losses in the stock market using our measures in the regressions. The purpose of these analyses are to show that they are useful indicators of systemic risk. Lastly in Section 4.3, we provide the most recent readings of our measures in 2018, as compared with 2014, to have a better sense of potential risk that the Korean economy faces due to interconnectedness among firms.

The unique features of the Korean economy motivate us to examine the following three, related, but distinct analyses of stock returns. The first analysis is at the market level by analyzing the largest stocks in the market. This resembles the usual analysis of the value-weighted stock market return, or the broad market index, as is most often employed in asset pricing tests. We choose the large 50 (or 36 in the PCA) stocks instead of working with a broader set of, e.g., 200 stocks in the Korean market. By expanding the set of stocks, our network measures would put relative more weights on small-sized stocks. As systemic risk is more likely to originate in a few larger stocks, our choice of the 50 largest stocks suits our purpose better. In addition, given the high concentration of market capitalization in relatively fewer number of stocks, our 
focus of the sample stocks has strong economic ground, based on the point of Gabaix (2011). The second analysis is based on chaebol returns that are constructed as value-weighted average of individual member firm returns. As the Korean economy is heavily concentrated on a few large chaebol groups and the commonality at the chaebol returns will also signal increased systemic risk. The third analysis employs industry returns. Given that the Korean economy is also highly concentrated in a few export-heavy industries, it is of particular interest to examine time-variation in commonalty at the industry level. We employ industry returns, which are value-weighted average of stock returns in the same industry, classified by the Korean stock exchange.

\section{Systemic Risk in Korea: Full Sample Analysis from 1995 to 2018}

\subsection{Principal Component Analysis: Graphical Illustration}

We first examine the commonality in the Korean stock market using the PCA. To the extent that heightened levels of systemic risk manifest as increased common movement in the largest stocks in the market, the PCA can provide an indication of increasing degrees of systemic risk. We perform the PCA using three-year rolling estimation windows (and thus we limit to the largest 36 stocks in the PCA).

In Figure 1, we plot the fraction of system variance explained by the largest principal components during our sample period as well as up to the tenth principal components, using the three sets of stock returns series (i.e., the largest 36 stocks, chaebols, and industries).

Figure 1A plots the fraction of variance explained by the principal components, using the largest 36 stock returns. A few observations are in order. There is a pronounced downward trend in the first principal component over the period from 1995 through 2018, which might suggest a decreased level of systemic risk in Korea. In particular, since around 2015, the first principal component explain approximately $20 \%$ of total system variance, which contrasts with over $40 \%$ of total system variance in around 2010 and 1999, the periods following the 2008 financial crisis and Asian financial 
Figure 1. Cumulative PCA Plots

Figure 1A: Top 36 Stocks

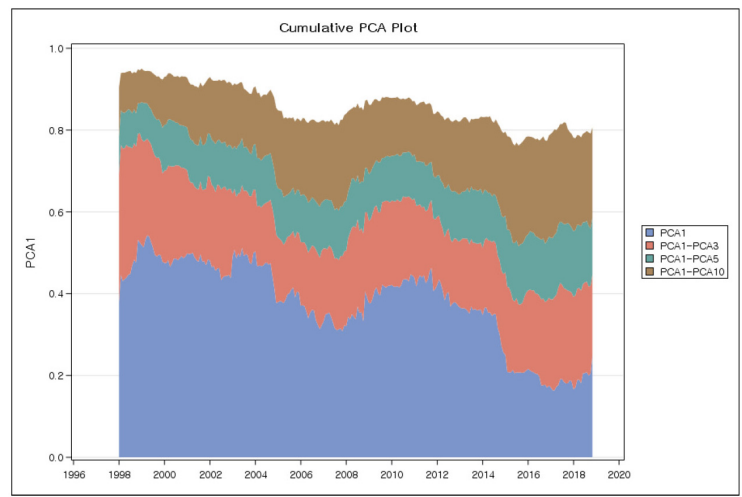

Figure 1B: Top 30 Chaebols

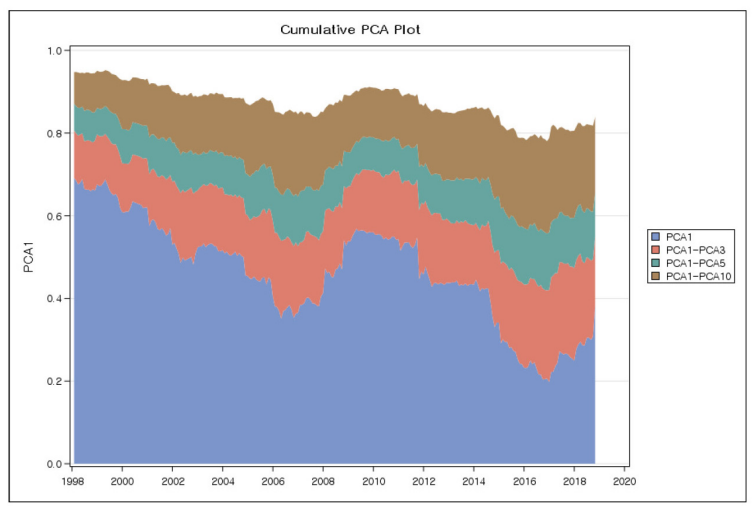

Figure 1C: KRX Industries

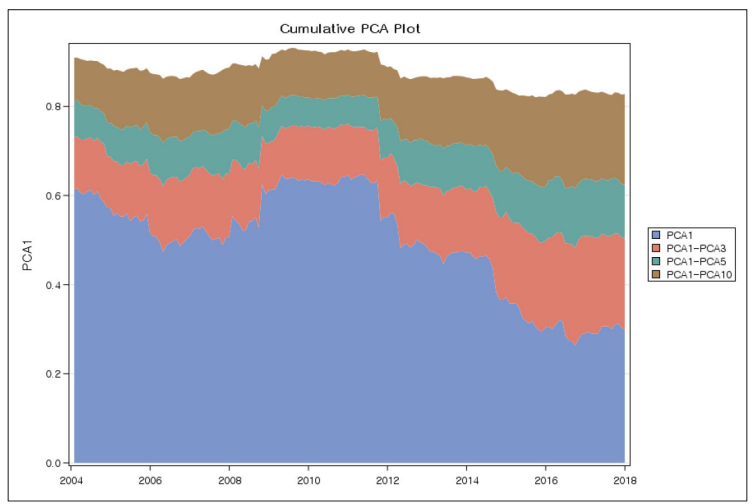


crisis, respectively. In sum, the figure from the PCA suggests that the level of systemic risk, as proxied by commonality in stock returns, has decreased to the lowest level since 1998.

Figures $1 \mathrm{~B}$ and $1 \mathrm{C}$ provide similar plots that show the fraction of variance explained by the first 10 principal components, but using returns on the 30 largest chaebols and KRX industries, respectively. These analyses complements the previous analysis using the largest 36 stocks, by encompassing larger universe of the Korean stock market. Both the figures depict largely similar pictures to Figure 1A. That is, systemic risk, as represented by commonality in stock returns, has decreased to the lowest levels since 1998. In Figure 1B, chaebol returns show slight increases towards the end of the sample period, which can suggest that there is systemic risk arising from chaebol groups. Other than this recent increase in systemic risk among chaebols, the cumulative PCA plots show that systemic risk in the Korean stock market is at the lowest level since 1998.

\subsection{Network Analysis}

In Figure 2, we plot the graphical representation of the Granger-causal links of the Korean stock market. We perform Granger-causality tests using 36 months rolling window estimation and establish a Granger-causal link from stock $i$ to $j$ if the corresponding coefficient from the Granger-causality test is positive with a statistical significance at the $10 \%$ level. Similar to the PCA plots provided in the previous section, we also apply the causality tests for the largest 50 stocks, the largest 30 chaebols, and the industry groups classified by the Korean stock exchange. To highlight how network connectedness can covary with systemic risk in the stock market, we provide three graphical representations of the network structure for the following five periods: the Asian crisis 1997-1999, the pre-financial crisis 2003-2005, the financial crisis 2007-2009, the post-financial crisis 2010-2012, the recent period 2016-2018.

The evolution of the network diagrams over our sample period, as plotted in Figure 2, shows that the increased connectedness in the stock market 


\section{BOK Working Paper No. 2020-8}

Figure 2. Network Diagram of Top 50 Stocks

Figure 2A: Asian Financial Crisis 1997-1999

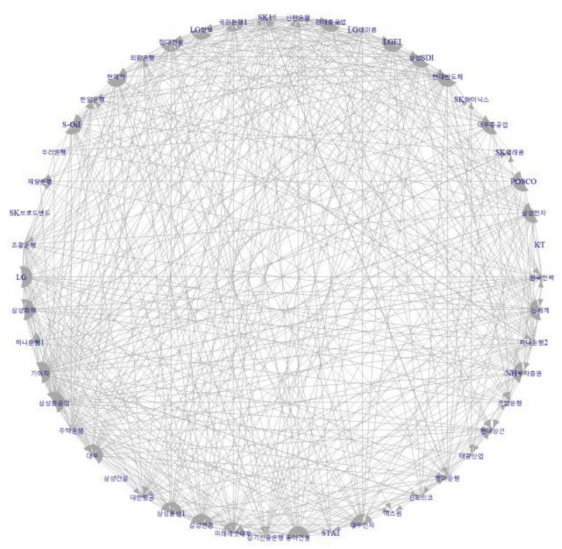

Figure 2C: The 2008 Financial Crisis 2007-2009

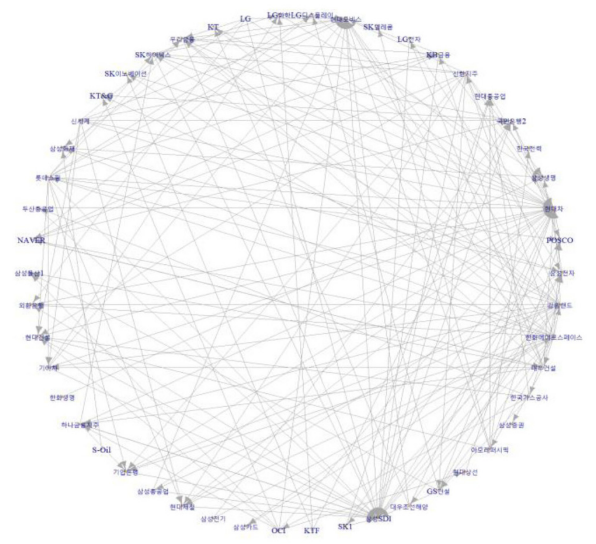

Figure 2B: Before the 2008 Financial Crisis 2003-2005

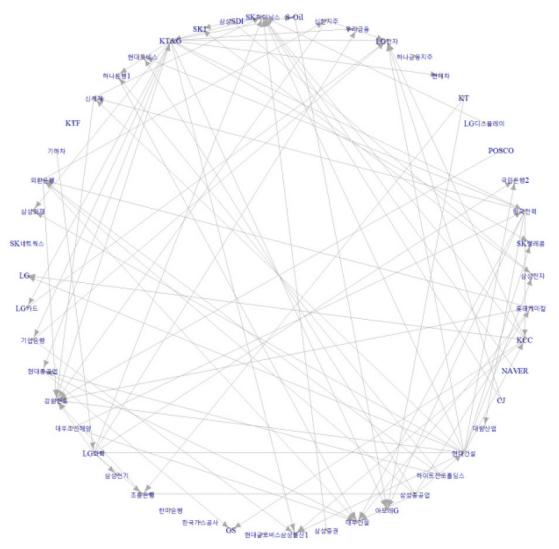

Figure 2D: After the 2008 Financial Crisis 2010-2012

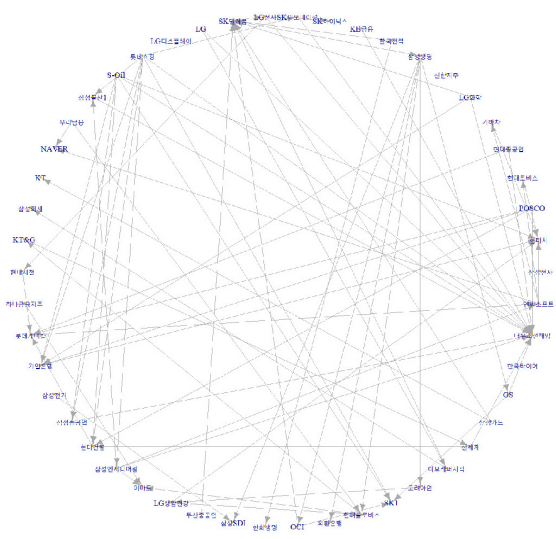

Figure 2E: The Recent Period 2016-2018

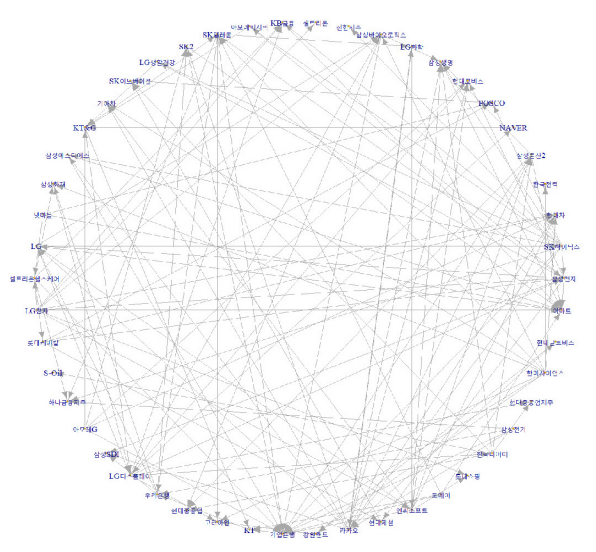


coincides with the periods that are typically characterized by increased systemic risk. First, note that the network diagrams plotted in Figures 2A through 2E show the dynamic nature of connectedness in major Korean stocks, thus suggesting the importance of monitoring the network structure in understanding the degrees of systemic risk in the stock market. Second, and perhaps more importantly, the connectedness of the system increases significantly during the crisis periods. In Figure 2A, for example, the network is highly connected, showing that systemic risk peaked during the Asian financial crisis. The connectedness of the system subsided significantly after the crisis, increased during the 2008 financial crisis shown in Figure 2C, and decreased again during mid 2010s in Figure 2D. We also plot the most recent network structure in Figure 2E, which shows a slightly more congested network structure.

In Table 1, we tabulate the two measures of connectedness (i.e., centrality and the number of connections in the network) as well as two relative principal components from the estimation of the PCA (i.e., the fractions of system variance explained by the first principal component and the sum of the second and third principal components, denoted as $\lambda_{1}$ and $\lambda_{2}+\lambda_{3}$, respectively) over the major sub-periods in our sample. We take average of node-level eigenvalue centrality to obtain network-level centrality. We report the results for the largest 50 stocks (the first lines in each panel), the top 30 chaebols (the second lines in each panel), and the KRX industries (the third lines in each panel). The industry classification is available only from 2000, and thus we do not have report industry-level results in Panels A and B.

The results in Table 1 show that our measures capture systemic risk in a timely manner. Focus first on the systemic risk measures using top 50 stocks (the first lines of each panel). Note that the measures already signal increased systemic risk even before the Asian financial crisis (see Panel A for January 1994 - December 1996): the network centrality was even higher at 0.124 than the Asian financial crisis period 0.116. The other measures, except for lambda 1 , also show that connectedness in the system has already peaked before the crisis, while lambda 1 shows that commonality among stocks is at the highest during the Asian financial crisis period. 
Table 1. Commonality and Connectedness Measures for the Six Sub-periods

\begin{tabular}{|c|c|c|c|c|}
\hline & $\lambda_{1}$ & $\lambda_{2}+\lambda_{3}$ & \# of Links & Centrality \\
\hline Top 50 firms & 0.378 & 0.316 & 304 & 0.124 \\
\hline Top 30 chaebols & 0.533 & 0.210 & 62 & 0.036 \\
\hline Industry sectors & NA & NA & NA & NA \\
\hline \multicolumn{5}{|c|}{ Panel B: January 1997 - December 1999 (IMF) } \\
\hline & $\lambda_{1}$ & $\lambda_{2}+\lambda_{3}$ & \# of Links & Centrality \\
\hline Top 50 firms & 0.475 & 0.285 & 285 & 0.116 \\
\hline Top 30 chaebols & 0.609 & 0.164 & 123 & 0.141 \\
\hline Industry sectors & NA & NA & NA & NA \\
\hline
\end{tabular}

Panel C: January 2004 - December 2006 (Before Financial Crisis)

\begin{tabular}{l|c|c|c|c} 
& $\lambda_{1}$ & $\lambda_{2}+\lambda_{3}$ & \# of Links & Centrality \\
\hline Top 50 firms & 0.332 & 0.240 & 120 & 0.049 \\
\hline Top 30 chaebols & 0.366 & 0.225 & 56 & 0.064 \\
\hline Industry sectors & 0.507 & 0.185 & 67 & 0.063
\end{tabular}

Panel D: January 2007 - December 2009 (Financial Crisis)

\begin{tabular}{l|c|c|c|c} 
& $\lambda_{1}$ & $\lambda_{2}+\lambda_{3}$ & \# of Links & Centrality \\
\hline Top 50 firms & 0.421 & 0.269 & 143 & 0.058 \\
\hline Top 30 chaebols & 0.560 & 0.191 & 52 & 0.060 \\
\hline Industry sectors & 0.636 & 0.154 & 121 & 0.108
\end{tabular}

Panel E: January 2010 - December 2012 (Post Financial Crisis)

\begin{tabular}{l|c|c|c|c} 
& $\lambda_{1}$ & $\lambda_{2}+\lambda_{3}$ & \# of Links & Centrality \\
\hline Top 50 firms & 0.366 & 0.163 & 77 & 0.031 \\
\hline Top 30 chaebols & 0.437 & 0.152 & 30 & 0.034 \\
\hline Industry sectors & 0.484 & 0.139 & 42 & 0.042
\end{tabular}

\begin{tabular}{l|c|c|c|c}
\hline Panel F: January $2016-$ December 2018 (Recent Period) \\
\hline & $\lambda_{1}$ & $\lambda_{2}+\lambda_{3}$ & \# of Links & Centrality \\
\hline Top 50 firms & 0.324 & 0.281 & 137 & 0.056 \\
\hline Top 30 chaebols & 0.459 & 0.242 & 39 & 0.045 \\
\hline Industry sectors & 0.332 & 0.346 & 67 & 0.068 \\
\hline
\end{tabular}

Table 1 also shows an interesting trend in the recent sample period. In particular, Panel F exhibits that systemic risk in the stock market has slightly risen since 2016. Across all the measures, except for the commonality measure based on the PCA shows increased values of network connectedness, compared with the early 2010 period. For example, the network centrality is 0.056 for the top 50 firms, a comparable level to the 2008 financial crisis (0.058), but a much higher value than the post financial crisis period (0.031). We find 
Figure 3. The Fraction of Network Connections to the Total Possible Connections: the Top 50 Stocks Analysis

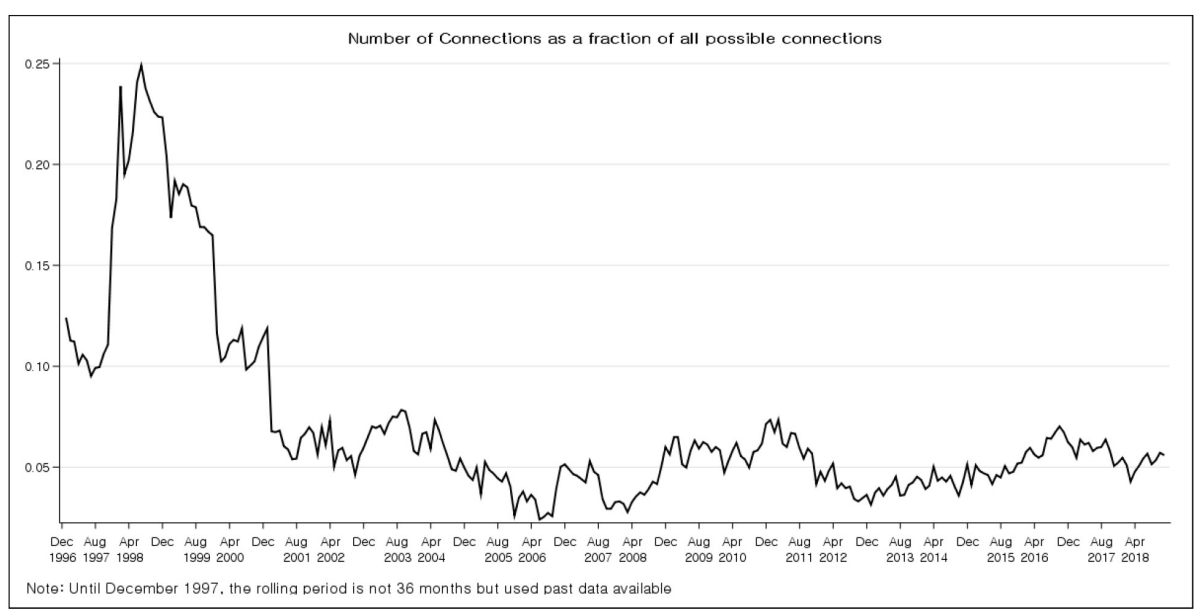

similar results for other network measures. The only exception is the commonality measure (the fraction of the first principal component), which is lower than the post-financial crisis period. Given that the commonality measure tends to be the highest at peak of the crisis (see the results in Panel $\mathrm{A}$ and Panel B), these results in Panel F can suggest systemic risk has increased in the recent years and regulators might want to pay more attention to see whether this is a temporary spike or signals an early warning.

In Figure 3, we also plot the fraction of the number of connections in the network relative to all possible connections. The figure shows that since the Asian financial crisis, connectedness in the stock market has subsided significantly. Even during the peak of the 2008 financial crisis, connectedness in the system did not increase very much, around at 0.06, a much lower level compared with the Asian financial crisis. (Note that we use rolling 36 months windows. Apr 2010 represent the fraction of connections estimated using data from May 2008 through Apr 2010). Interestingly, there is increased connectedness in the later period of the sample, e.g., since 2016, almost to the level of the financial crisis period.

In sum, our empirical evidence shows that both the levels of commonality and connectedness have dramatically decreased since the period of the Asian 


\section{$21 \quad$ BOK Working Paper No. 2020-8}

financial crisis except for a slight increase during the period of the 2008 financial crisis. In comparing two crises, systemic risk in the Asian financial crisis is much higher than that of the 2008 financial crisis, consistent with the existing studies that the 2008 financial crisis, different from the events of the Asian financial crisis, has less impact on the Korean economy (Cho and Shin, 2012; Emmer and Ravenhill, 2011; Goldstein and Xie, 2009). This result can be interpreted that our measure tends to detect the risk from the insolvency of the corporate sector (i.e., Asian financial crisis) well rather than the risk from the collapse of the financial sector (i.e., the 2008 financial crisis).

\section{Correlations between Systemic Measures and Alternative Measures}

In this section, we compare the patterns of our systemic measures with those of alternative measures that previous literature has commonly used (e.g., credit spread, financial stability index, and term spread).

Specifically, in Figure 4A, we plot our PCA measure of the top 50 stocks with credit spreads, term spreads, and the financial stability index, using rolling 36 months windows. Similarly, in Figure 4B we also plot correlations of our measure for the chaebol group's systemic risk with the three macroeconomic variables. In Figure 4C, we also plot the correlations between the connection measure and the three macroeconomic variables. In the three plots, we find in general high levels of correlations but they also fluctuate over time. In particular, the correlations with the financial stability index tend to be high in the earlier part of the sample, which indicates that our measure and the financial stability index capture similar variation of systematic risk. At the same time, we also find that in the later part of the sample, the correlations are sometimes below zero, which also suggests that the two measures also represent somewhat distinct aspects of systemic risk. 
Figure 4. Correlations between our Systemic Risks and Alternative Measures Figure 4A: PCA of the Top 50 Stocks

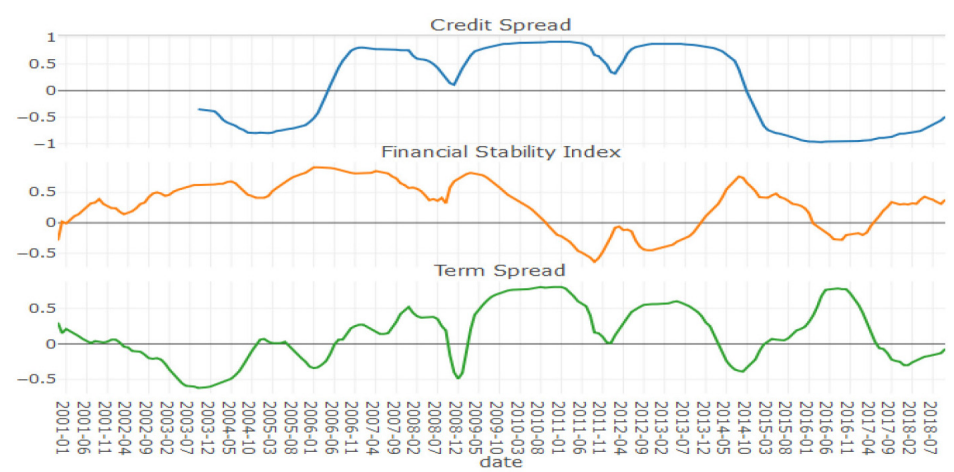

Note: We plot our PCA measure of the top 50 stocks with credit spreads, term spreads, and the financial stability index, using rolling 36 months windows

Figure 4B: PCA of the Top 30 Chaebols

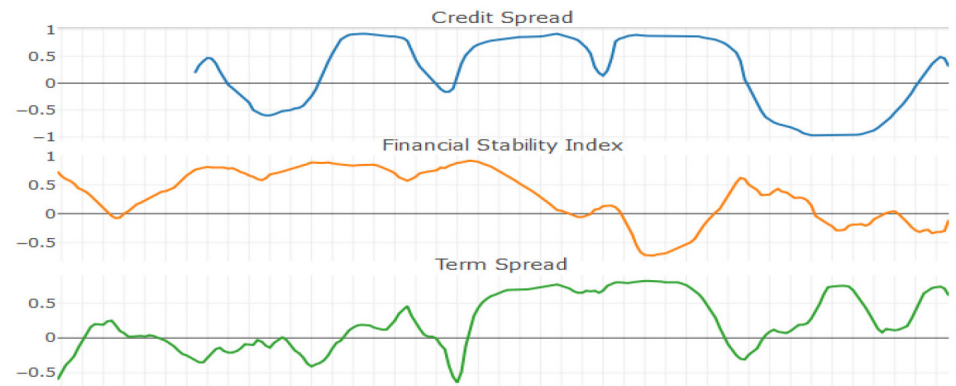

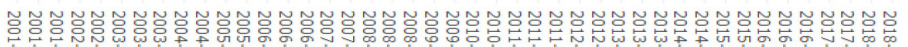

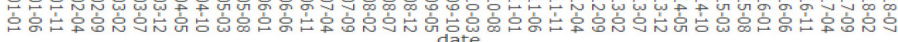

Note: We plot our PCA measure of the top 30 Chaebol stocks with credit spreads, term spreads, and the financial stability index, using rolling 36 months windows

Figure 4C: Connection

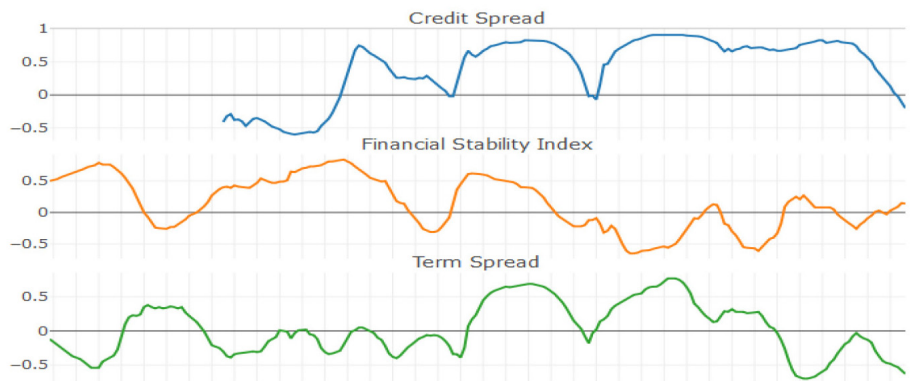

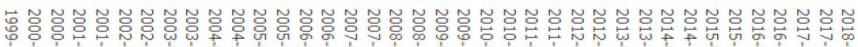

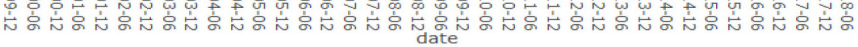

Note: We plot our network connection measure of the top 50 stocks stocks with credit spreads, term spreads, and financial stability index, using rolling 36 months windows. 


\section{Predicting Stock Market Loss Using the Systemic Risk Measures}

The previous analyses show that our measures of systemic risk capture the connectedness and commonality in advance of the crisis periods. An important check that we need to further perform is whether these measures would have helped regulators detect potential risk in the system prior to the systemic events.

For this purpose, we examine whether our measures that are estimated before the crisis periods can predict losses in the stock market during the crises. Losses in the stock market are measured as maximum losses during our prediction periods. Specifically, we compute maximum percentage losses in market capitalization (MaxLoss) experienced by the 50 largest firms in the Korean stock market. The maximum percentage loss is defined as the difference between the market capitalizations of stocks at the beginning of the prediction period and their minimum market capitalizations during the next twelve months period from the beginning of the period, divided by the market capitalizations at the beginning of the prediction period. We calculate MaxLoss for the 50 largest stocks, separately.

To examine the predictive power of our systemic risk measures, we also calculate connectedness measures for the 50 stocks. In particular, we calculate the following five measures for each of the 50 stocks: eigenvector centrality, closeness, the number of out links, the number of in-links, and the number of total links. The eigenvector centrality measure is the column vector item of the eigenvector of the adjacency matrix associated with the eigenvalue of one. The other four measures are based on the definition provided in Section 2. The measures are all calculated at the node-level to perform cross-sectional regression.

We explore the predictive power of these connectedness measures using the regressions of MaxLoss. We use the following two sample periods for the crises. The first crisis period is the one year period from September 1997, the onset of the Asian financial crisis. The second crisis period is the one year period from August 2008, the onset of the 2008 financial crisis. To avoid any 
Table 2. Predicting Stock Market Loss Using Network Measures

\begin{tabular}{|l|c|c|c}
\multicolumn{1}{c}{ Panel A: The Asian Financial Crisis Period } \\
\hline Centrality & Coeff & t-statistic & $R^{2}$ \\
\hline Closeness & -0.226 & -2.11 & $8.7 \%$ \\
\hline \# of Out Connections & -0.419 & -2.65 & $13.0 \%$ \\
\hline \# of In Connections & -0.807 & -2.02 & $8.0 \%$ \\
\hline \# of All Connections & 0.226 & 0.34 & $0.2 \%$ \\
\hline
\end{tabular}

Panel B: The 2008 Financial Crisis Period

\begin{tabular}{l|c|c|c} 
& Coeff & t-statistic & $R^{2}$ \\
\hline Centrality & -0.247 & -3.39 & $10.6 \%$ \\
\hline Closeness & -0.064 & -1.08 & $1.2 \%$ \\
\hline \# of Out Connections & -0.441 & -1.93 & $3.7 \%$ \\
\hline \# of In Connections & -0.353 & -1.11 & $1.3 \%$ \\
\hline \# of All Connections & -0.470 & -2.40 & $5.6 \%$ \\
\hline
\end{tabular}

look-ahead biases, we separate the network estimation period and the prediction period. The estimation period is the three year periods preceding the beginning of these two prediction periods, that is, September 1997 and August 2008. In Table 2, we run the regressions of MaxLoss on the connectedness measures separately for the two sample periods.

The results provided in Table 2 show that our connectedness measures exhibit strong predictive power for future losses in the stock market during these sub-periods of financial crisis. In Panel A, for example, the coefficient estimates on the five systemic risk measures considered tend to be negative and statistically significant at the conventional levels. For example, the coefficient on centrality is -0.226 with a t-statistic of -2.11 . The only measure that is not significantly associated with future MaxLoss is the number of in-connections. Panel B presents similar results. That is, the systemic risk measures are all negatively associated with future MaxLoss. Three of the five measures considered are statistically significant at the conventional levels. In sum, the results in Table 2 show that increased values of these measures are associated with lower future market capitalization (i.e., greater maximum loss of market values), another evidence that suggests that the systemic risk 
measures based on the network analysis can be a helpful toolkit for regulators and policymakers.

\section{Recent Trend in Systemic Risk in Korea: Within Chaebol and Industry Analyses}

The previous results show that although systemic risk has subsided substantially and tends to be at a much lower level than in early 2010, the most recent readings of the measures indicate a slight increase in systemic risk. We investigate further by focusing on chaebols and industries. First, we examine connectedness within four major chaebol groups to relate to any potential risk of too-big-to-fail. We also examine within-industry connectedness in the major industry, that is, electronics, automobile, and banking industries, as these are particularly important ones for their roles in the Korean economy.

\subsection{Commonality and Connectedness in the Top Chaebols}

In Figure 5, we first provide the cumulative PCA graphs during our sample period for four major business groups. A few observations are made. First, overall commonality has decreased over time for all of the four chaebols, as indicated by the downward trend in the first principal component. Second, despite the common downward trend among the four, there is cross-sectional variation in the trend. Of the four, Group D has the lowest level of commonality or the first principal component in the recent period, suggesting that their member firms do not covary with each other too much and thus Group D has relatively lower level of common risk among their member firms. In comparison, Group B exhibits high level of commonality even in the most recent period relative to the other groups. In fact, commonality has not decreased much since early 2010, unlike other chaebol groups. 
Figure 5. Cumulative PCA Plots of Top Chaebols

Figure 5A: Group A

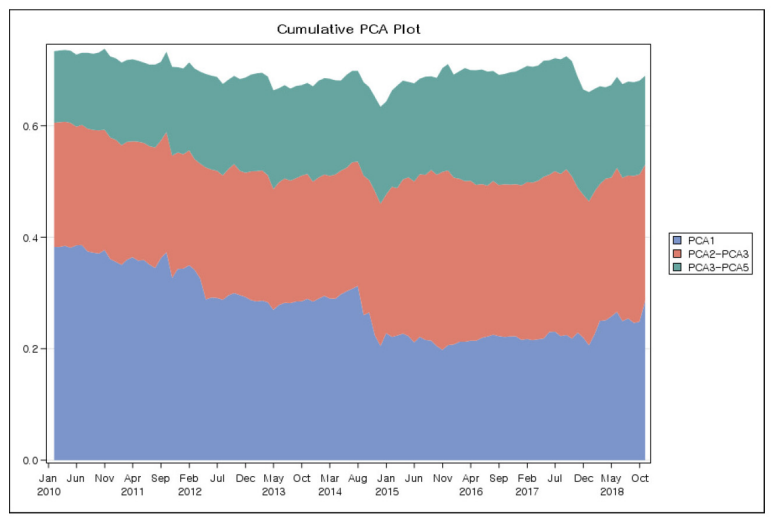

Figure 5B: Group B

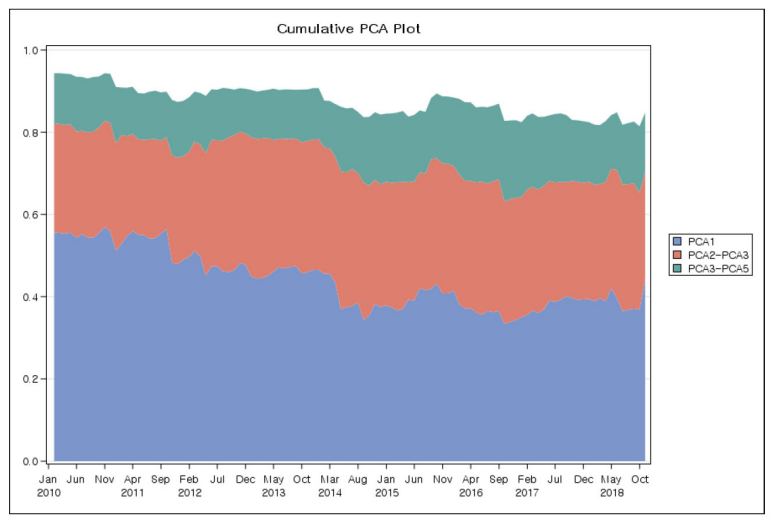

Figure 5C: Group C

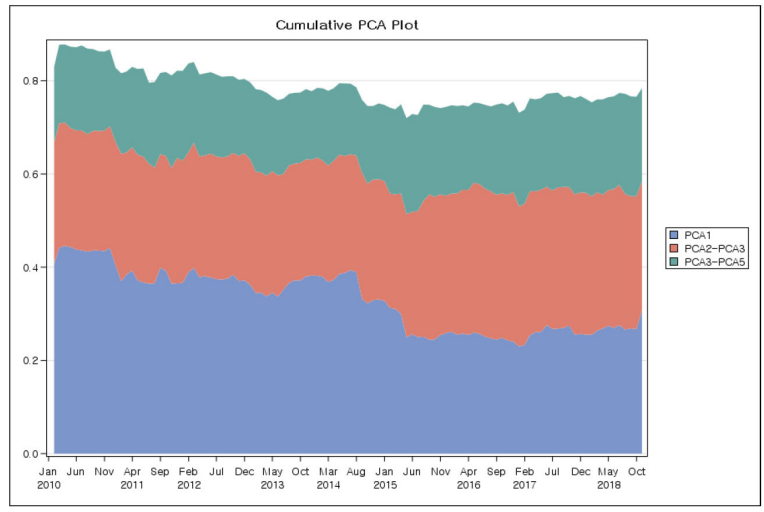


Figure 5D: Group D

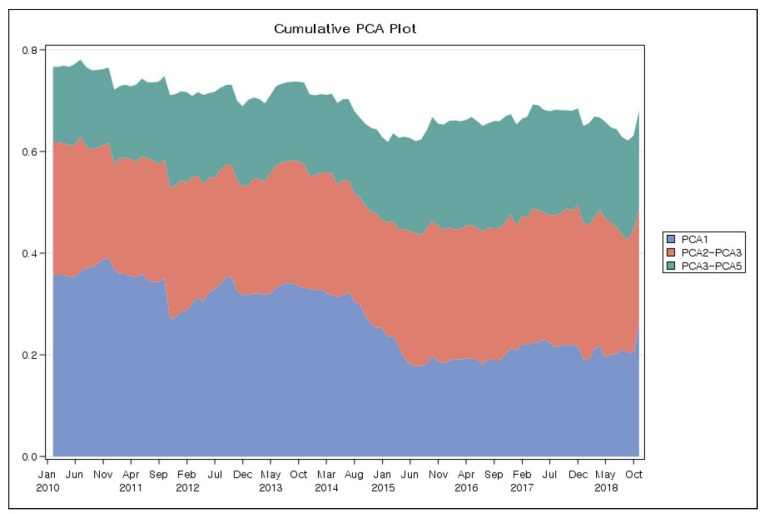

In Table 3, we tabulate changes in our measures of systemic risk between the two sub-periods, 2012 to 2014 and 2015 to 2018 . We report the fraction of system variance explained by the first principal component $\left(\lambda_{1}\right)$, the number of connections in the Granger-causality network, and eigenvalue centrality for four chaebols as well as the top 50 firms for a comparison. The table depicts a mixed picture. First, there is no strong evidence that within-chaebol systemic risk has increased in the recent period even for Group B. If any, Group B has lower centrality measures than before, although their commonality has increased. Thus, the chaebol is subject to high degrees of common shocks, but there does not exist strong causal links within the chaebol. In comparison, some chaebols exhibit increases in all measures of commonality and connectedness. For example, $\lambda_{1}$ increases from 0.228 to 0.286 and centrality increases from 0.026 to 0.044 for Group A. These last pieces of results suggest a slight increase in concentration and connectedness in some chaebols, which can be driven by the relative importance of their key member firms in the semiconductor industry in the recent years. In sum, overall systemic risk in chaebols is not a significant concern in Korea because the measures of commonality and connectedness show either the mixed evidence or only a slightly increasing trend. 


\section{Table 3. Current Readings of Commonality and Connectedness in the Korean Stock Market: Top Chaebols}

Panel A: January 2012 - December 2014

\begin{tabular}{|l|c|c|c|} 
& $\lambda_{1}$ & \# of Connections & Centrality \\
\hline Top 50 firms & 0.251 & 101 & 0.041 \\
\hline Group A & 0.228 & 10 & 0.026 \\
\hline Group B & 0.379 & 7 & 0.064 \\
\hline Group C & 0.328 & 7 & 0.053 \\
\hline Group D & 0.252 & 26 & 0.076 \\
\hline
\end{tabular}

Panel B: November 2015 - October 2018

\begin{tabular}{|l|c|c|c|} 
& $\lambda_{1}$ & \# of Connections & Centrality \\
\hline Top 50 firms & 0.249 & 137 & 0.056 \\
\hline Group A & 0.286 & 12 & 0.044 \\
\hline Group B & 0.446 & 2 & 0.018 \\
\hline Group C & 0.308 & 12 & 0.091 \\
\hline Group D & 0.264 & 23 & 0.061 \\
\hline
\end{tabular}

\subsection{Commonality and Connectedness in Industries: Electronics, Automobile, and Finance}

We further search for any evidence of increased commonality and connectedness in the major industries. We choose electronics, automobile, and finance, as these industries are arguably the basis of the Korean economy; the former two industries are among the most important export sectors in Korea and the finance industry is crucial in corporate financing given the heavy dependence of Korean firms on bank financing.

In Figure 6, we plot the cumulative the PCA graphs during our sample period for the three industries. The two manufacturing industries exhibit similar patterns that we observe the previous sections: there is a downward trend in commonality and it does not seem particularly high. In Figure 6C for the finance industry, however, we find a unique pattern that we do not observe in previous sections. ${ }^{11)}$ First, we find that commonality stays relative

11) In extending the sample between 1999 and 2018, we find that systemic risk in the finance sector has maintained at the constant level except for the increases during the periods of the credit card event (2002-2003) and the global financial crisis (2008) whereas systemic risk in the other manufacturing sectors has subsided since 1999 except for a slight increase during the global financial crisis. 
Table 4. Current Readings of Commonality and Connectedness in the Korean Stock Market: Major Industries

\begin{tabular}{l|c|c|c}
\multicolumn{4}{c}{ Panel A: January 2012 - December 2014 } \\
\hline Electronics & $\lambda_{1}$ & $\#$ of Connections & Centrality \\
\hline Automobile & 0.195 & 50 & 0.057 \\
\hline Finance & 0.233 & 31 & 0.036 \\
\hline
\end{tabular}

Panel B: November 2015 - October 2018

\begin{tabular}{l|c|c|c} 
& $\lambda_{1}$ & \# of Connections & Centrality \\
\hline Electronics & 0.197 & 47 & 0.054 \\
\hline Automobile & 0.346 & 33 & 0.038 \\
\hline Finance & 0.440 & 30 & 0.084 \\
\hline
\end{tabular}

flat over time. In other words, the banking sector in Korea does not show downward trend in commonality. Second, the level of commonality is relatively high at the $40 \%$ level throughout the period from 2010 to 2018. Given that 2010 is the year with heightened systemic risk due to the financial crisis, we interpret that systemic risk in the finance sector in Korea is related to the unique characteristics of the sector in which financial institutions trade frequently with each other.

To investigate further, in Table 4 we tabulate changes in our measures of systemic risk between the two sub-periods, 2012 to 2014 and 2015 to 2018 . As before, we report the fraction of system variance explained by the first principal component $\left(\lambda_{1}\right)$, the number of connections in the Granger-causality network, and eigenvalue centrality for the three sectors. The table shows that there is no big changes in the measures across the two periods among the sectors. For the finance industry, we find that the centrality and commonality are high relative to the other two sectors, suggesting that connectedness and commonality can amplify system-wide shocks in the banking sector. 
Figure 6. Cumulative PCA Plots of Major Industries

Figure 6A: Electronics

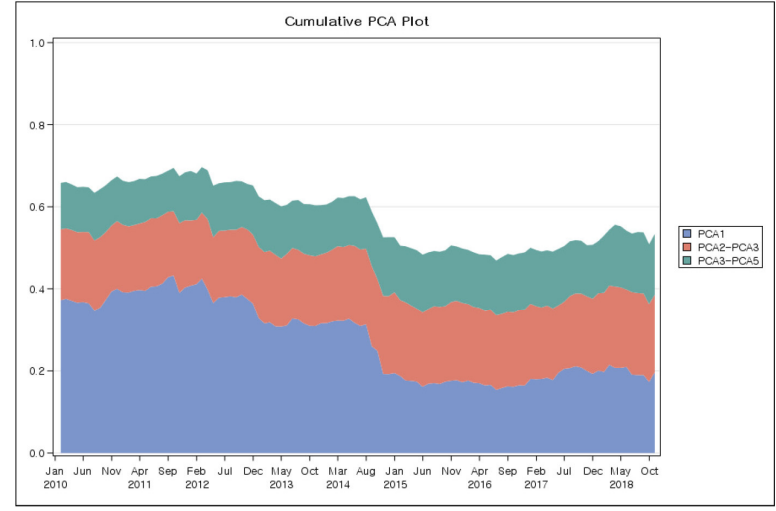

Figure 6B: Automobile

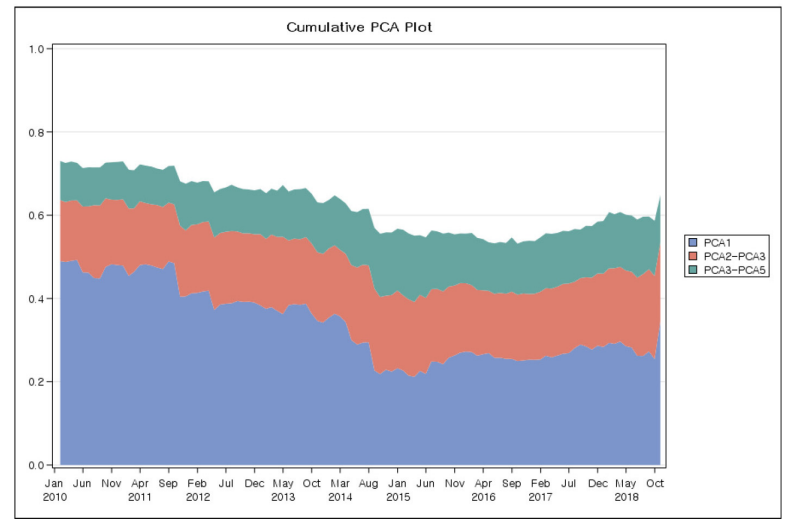

Figure 6C: Finance

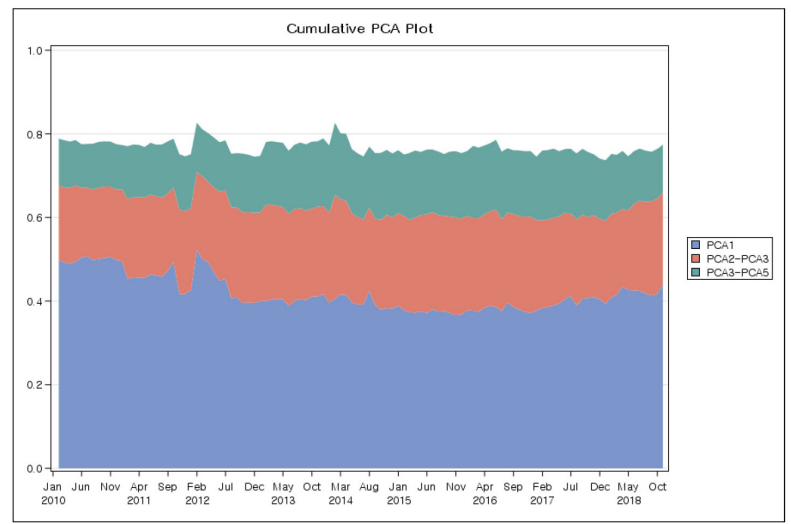




\section{BOK Working Paper No. 2020-8}

\section{Conclusion}

In this paper, we provide econometric measures of systemic risk based on commonality and connectedness that are adapted to the settings of the Korean market. We estimate relative contributions of system variance using the PCA and the Granger-causality network, following Billio et al. (2012) by exploiting the unique features of the Korean stock market: high concentration in large business groups and manufacturing-driven export sectors. In particular, we employ stock returns at the individual firm (including manufacturing firms), chaebol, and industry levels. We also provide within-chaebol and within-sector analyses of interconnectedness, thus examining how they are linked with each other.

Our results show that these econometric measures perform relatively well over our sample period. Our measures indicate heightened levels of commonality and interconnectedness during the Asian and 2008 financial crisis periods. In out-of-sample tests, we also show that the measures can predict future losses in the stock markets, particularly during the crisis periods. We also provide the recent readings of our measures, both at the market, chaebol, and industry levels. Although the measures indicate systemic risk is not a major concern in Korea, as they tend to be lowest since 1998, there is an increasing trend in commonality and connectedness since 2016. Some chaebols exhibit increasing degrees of commonality and connectedness, perhaps because of their heavy dependence on a few major member firms. Commonality in the finance industry has not subsided to a lower level since the financial crisis, which seems to be related to the unique feature of the industry where financial institutions trade frequently between them. It is interesting future research to further examine the extent to which network-based systemic risk measures can be used as early warning signal of future crises. 


\section{References}

Acharya, V. V., L. H. Pedersen, T. Philippon, and M. Richardson (2017), "Measuring Systemic Risk," Review of Financial Studies, Vol. 30(1), pp. 2-47.

Adrian, T., and M. K. Brunnermeier (2016), “CoVaR," American Economic Review, Vol. 106(7), pp. 1705-1741.

Amihud, Y., and H. Mendelson (1986), “Asset Pricing and the Bid-Ask Spread, Journal of Financial Economics, Vol. 17(2), pp. 223-249.

Battiston, S., D. Delli Gatti, M. Gallegati, B. C. Greenwald, and J. E. Stiglitz (2012), "Liasons Dangereuses: Increasing Connectivity, Risk Sharing, and Systemic Risk," Journal of Economic Dynamics and Control, Vol. 36(8), pp. 1121-1141.

Benoit, S., J. E. Colliard, C. Hurlin, and C. Pérignon (2017), "Where the Risks Lie: A Survey on Systemic Risk,” Review of Finance, Vol. 21(1), pp. 109-152.

Bisias, D., M. Flood, A. W. Lo, and S. Valavanis (2012), "A Survey of Systemic Risk Analytics," Annual Review of Financial Economics, Vol. 4(1), pp. 255-296.

Billio, M., M. Getmansky, A. W. Lo, and L. Pelizzon (2012), "Econometric Measures of Connectedness and Systemic Risk in the Finance and Insurance Sectors," Journal of Financial Economics, Vol. 104(3), pp. 535-559.

Billio, M., M. Getmansky, and L. Pelizzon (2011), "Crises and Hedge Fund Risks," Unpublished working paper, Ca' Foscari University of Venice and University of Massachusetts at Amherst.

Billio, M., and L. Pelizzon (2000), "Value-at-Risk: A Multivariate Switching Regime Approach," Journal of Empirical Finance, Vol. 7(5), pp. 531-554.

Borio, C. E., and M. Drehmann (2009), "Assessing the Risk of Banking Crises-Revisited," BIS Quarterly Review, March.

Brennan, M. J., T. Chordia, and A. Subrahmanyam (1998), "Alternative Factor 
Specifications, Security Characteristics and the Cross-Section of Expected Stock Returns," Journal of Financial Economics, Vol. 49(3), pp. 345-373.

Brownlees, C. T., and R. F. Engle (2016), "SRISK: A Conditional Capital Shortfall Index for Systemic Risk Measurement" Review of Financial Studies, Vol. 30(1), pp. 48-79.

Buraschi, A., P. Porchia, and F. Trojani (2010), "The Cross-Section of Expected Stock Returns: Learning about Distress and Predictability in Heterogeneous Orchards," Unpublished working paper, Imperial College, IE Business School, and Swiss Finance Institute.

Castiglionesi, F., F. Feriozzi, and G. Lorenzoni (2009), "Financial Integration, Liquidity, and the Depth of Systemic Crisis," Unpublished working paper, Massachusetts Institute of Technology and University of Tilburg.

Cho, D., and S. Shin (2012), "Crisis and Employment: The Case of Korea," Journal of Policy Analysis and Management, Vol. 31(1), pp. 169-177.

Chordia, T., R. Roll, and A. Subrahmanyam (2000), "Commonality in Liquidity," Journal of Financial Economics, Vol. 56(1), pp. 3-28.

Chordia, T., R. Roll, and A. Subrahmanyam (2001), "Market Liquidity and Trading Activity," The Journal of Finance, Vol. 56(2), pp. 501-530.

Chordia, T., R. Roll, and A. Subrahmanyam (2002), "Order Imbalance, Liquidity and Market Returns," Journal of Financial Economics, Vol. 65(1), pp. 111-130.

Danielsson, J., H. S. Shin, and J. P. Zigrand (2011), "Balance Sheet Capacity and Endogenous Risk," Unpublished working paper, London School of Economics and Princeton University.

De Bandt, O., and P. Hartmann (2000), "Systemic Risk: A Survey," European Central Bank Working Paper, No. 35. 
Emmers, R., and J. Ravenhill (2011), "The Asian and Global Financial Crises: Consequences for East Asian Regionalism," Contemporary Politics, Vol. 17(2), pp. 133-149.

Financial Stability Board (FSB) (2009), "Guidance to Assess the Systemic Importance of Financial Institutions, Markets and Instruments: Initial Considerations," Report to G20 Finance Ministers and Central Bank Governors, IMF/BIS/FSB.

Bank of Korea (2018), Financial Stability Report, Dec. 2018.

Gabaix, X. (2011), "The Granular Origins of Aggregate Fluctuations," Econometrica, Vol. 79(3), pp. 733-772.

Getmansky, M., A. W. Lo, and I. Makarov (2004), “An Econometric Model of Serial Correlation and Illiquidity in Hedge Fund Returns," Journal of Financial Economics, Vol. 74(3), pp. 529-609.

Glosten, L., and L. Harris (1988), "Estimating the Components of the Bid/Ask Spread," Journal of Financial Economics, Vol. 21(1), pp. 123-142.

Goldstein, M., and D. Xie (2009), "The Impact of the Financial Crisis on Emerging Asia,” Peterson Institute for International Economics Working Paper, No. 09-11.

Huang, X., H. Zhou, and H. Zhu (2012), "Systemic Risk Contributions," Journal of Financial Services Research, Vol. 42(1), pp. 55-83.

Lee, K. Y. (2015), "Measuring Systemic Risk Using Principal Components Analysis," Journal of Money and Finance, Vol. 29, pp. 32-58.

Lillo, F., J. D. Farmer, and R. N. Mantegna (2003), "Econophysics: Master Curve for Price-Impact Function," Nature, Vol. 421(6919), pp. 129-130.

Lo, A. W., and J. Wang (2000), "Trading Volume: Definitions, Data Analysis, and Implications of Portfolio Theory," The Review of Financial Studies, Vol. 13(2), pp. 257-300. 
Lo, A. W. (2001), "Risk Management for Hedge Funds: Introduction and Overview," Financial Analysts Journal, Vol. 57(6), pp. 16-33.

Lo, A. W., H. Mamaysky, and J. Wang (2001), "Foundations of Technical Analysis: Computational Algorithms, Statistical Inference, and Empirical Implementation," The Journal of Finance, Vol. 55(4), pp. 1705-1765.

Pastor, L., and R. Stambaugh (2003), "Liquidity Risk and Expected Stock Returns," Journal of Political Economy, Vol. 111(3), pp. 642-685.

Reinhart, C. M., and K. S. Rogoff (2009), This Time Is Different: Eight Centuries of Financial Folly, Princeton University Press, Princeton, NJ.

Sadka, R. (2006), "Momentum and Post-Earnings-Announcement Drift Anomalies: the Role of Liquidity Risk," Journal of Financial Economics, Vol. 80(2), pp. 309-349.

Scholes, M., and J. Williams (1977), "Estimating Betas from Nonsynchronous Data," Journal of Financial Economics, Vol. 5(3), pp. 309-327.

Seo, H. D. (2014), "Analyzing Interconnectedness in Korean Financial Industry Using Granger Causality Network," Research papers, No. 14-04, Korea Capital Market Institute, pp. 1-96. 


\title{
$<$ Abstract in Korean $>$
}

\section{네트워크 모형에 기반한 국내 기업부문 시스템 리스크 측정}

\author{
최재원*, 이지은**
}

본고에서는 1994 2018년 기간 중 상위 50개 시가총액 기업, 상위 30 개 대기 업 집단, 전기·전자, 자동차, 금융업을 포함하는 개별 산업 등 다양한 기업군 및 산 업을 대상으로 동 분류에 속한 개별 기업의 월별 주가수익률 간 동행성과 연계성 을 측정함으로써 시스템 리스크를 시산하고 동 지표의 유용성을 살펴보았다. 분석 결과, 시가총액 상위기업, 대기업 집단, 주요 산업 간 주가수익률의 동행성과 연계 성은 위기 시 큰 폭으로 상승하는 것으로 나타났다. 아울러 표본 외 예측을 시행한 결과 시산한 시스템 리스크 지표가 위기기간 중 주식시장의 기대손실을 잘 포착하 는 것으로 추정되었다. 2010년 이후 대기업 집단 및 개별 산업 내 동행성과 연계성 을 측정해보면 동 수치가 최근 수년 간 최저 수준을 유지하는 것으로 나타났는데, 이는 최근 개별 대기업 집단과 개별 산업의 시스템 리스크가 양호함을 시사한다. 다만, 여타 산업과 달리 금융업의 동행성과 연계성은 그 수치가 크게 하락하지 않 았는데, 이러한 결과는 금융업의 시스템 리스크가 낮아지지 않았다기보다는 금융 기관 간 거래가 빈번하게 이루어지는 금융업의 특성이 반영된 것으로 보여진다. 본고에서 제시하고 있는 시스템 리스크 측정 방법은 재무제표에 비해 공표주기가 짧고 쉽게 입수가능하며 미래 기대가 반영된 주가자료를 활용하고 있다는 점에서 시스템 리스크 변화를 빠르게 포착 가능할 뿐 아니라 기업 부문 부실에서 축적될 수 있는 시스템 리스크를 감지하는 데 비교우위가 있는 만큼 금융기관 간 네트워 크에 기반한 기존의 시스템 리스크 지표를 보완하는 지표로 활용 가능할 것으로 기대된다.

핵심 주제어: 시스템 리스크, 네트워크 분석, 한국경제

JEL Classification: G11, G14, G23

* 일리노이대 경영대학 교수/연세대학교 경영대학 부교수 (전화: +1-217-244-0840, E-mail: jaewchoi@illinois.edu)

** 한국은행 경제연구원 금융통화연구실 부연구위원 (전화: 02-759-5470, E-mail: jelee@bok.or.kr)

이 연구내용은 집필자의 개인의견이며 한국은행의 공식견해와 무관합니다. 따라서 본 논문의 내용을 보도하거나 인용할 경우에는 집필자명을 반드시 명시하여주시기 바랍니다. 


\section{$\mathrm{BOK}$ 경제연구 발간목록}

한국은행 경제연구원에서는 Working Paper인 ${ }^{\mathrm{BOOK}}$ 경제연구』를 수시로 발간하고 있습니다.

『BOK 경제연구』는 주요 경제 현상 및 정책 효과에 대한 직관적 설명 뿐 아니라 깊이 있는 이론 또는 실증 분석을 제공함으로써 엄밀한 논증에 초점을 두는 학술논문 형태의 연구이며 한국은행 직원 및 한국은행 연구용역사업의 연구 결과물이 수록되고 있습니다.

『BOK 경제연구』는 한국은행 경제연구원 홈페이지(http://imer.bok.or.kr)에서 다운로드하여 보실 수 있습니다.

제2017-1 가계부채가 소비와 경제성장에 미치는 영향 강종구

- 유량효과와 저량효과 분석 -

2 Which Monetary Shocks Matter in

Jongrim $\mathrm{Ha} \cdot$

Small Open Economies? Evidence from

Inhwan So

SVARS

3 FTA의 물가 안정화 효과 분석

곽노선 · 임호성

4 The Effect of Labor Market Polarization on Sungyup Chung the College Students' Employment

5 국내 자영업의 폐업률 결정요인 분석 남윤미

6 차주별 패널자료를 이용한 주택담보대출의 정호성 연체요인에 대한 연구

7 국면전환 확산과정모형을 이용한 콜금리행태 최승문 - 김병국 분석

8 Behavioral Aspects of Household Portfolio In Do Hwang Choice: Effects of Loss Aversion on Life Insurance Uptake and Savings

9 신용공급 충격이 재화별 소비에 미치는 영향 김광환 - 최석기

10 유가가 손익분기인플레이션에 미치는 영향 김진용·김준철·임형준

11 인구구조변화가 인플레이션의 장기 추세에 강환구 미치는 영향

12 종합적 상환여건을 반영한 과다부채 가계의 이동진 - 한진현 리스크 요인 분석

13 Crowding out in a Dual Currency

Regime? Digital versus Fiat Currency

KiHoon Hong • Kyounghoon Park • Jongmin $\mathrm{Yu}$ 


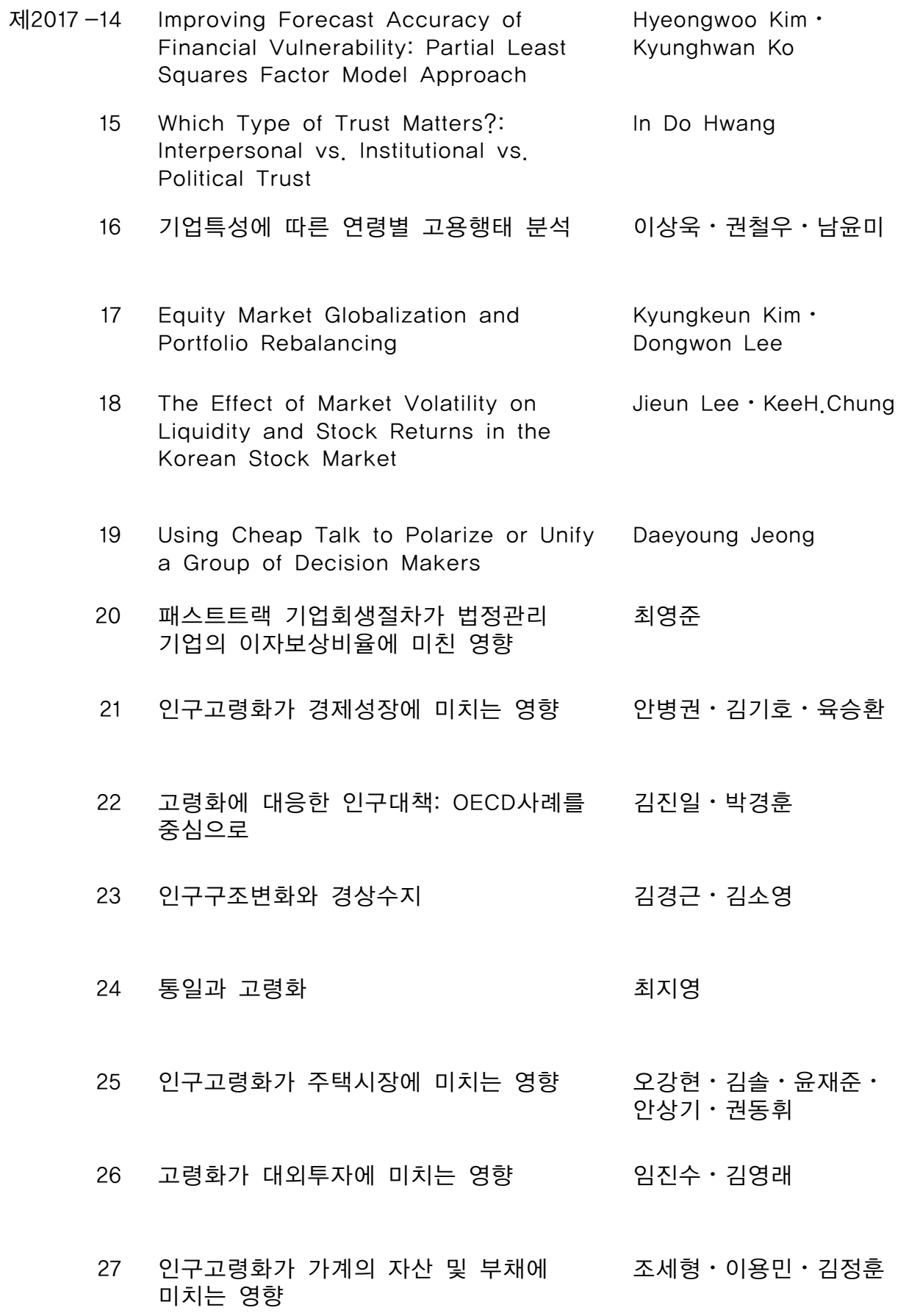

안병권 · 김기호 · 육승환

김경근 · 김소영

임진수 · 김영래

27 인구고령화가 가계의 자산 및 부채에 미치는 영향

Hyeongwoo Kim •

Kyunghwan Ko

In Do Hwang

Daeyoung Jeong

최영준

조세형·이용민·김정훈 


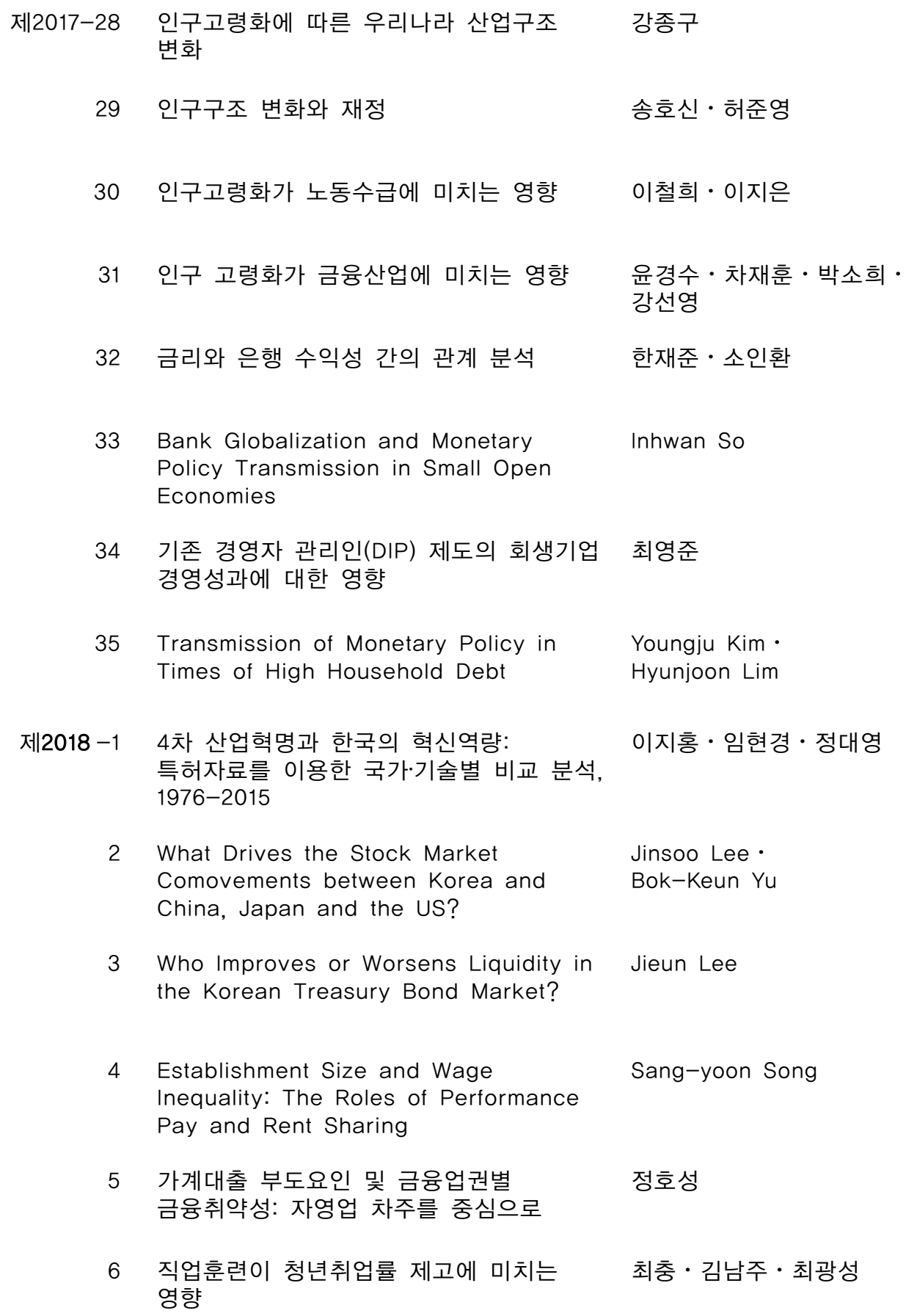

29 인구구조 변화와 재정

30 인구고령화가 노동수급에 미치는 영향

31 인구 고령화가 금융산업에 미치는 영향

32 금리와 은행 수익성 간의 관계 분석

33 Bank Globalization and Monetary Policy Transmission in Small Open Economies

34 기존 경영자 관리인(DIP) 제도의 회생기업 경영성과에 대한 영향

35 Transmission of Monetary Policy in Times of High Household Debt

제2018-1 4차 산업혁명과 한국의 혁신역량:

특허자료를 이용한 국가-기술별 비교 분석, 1976-2015

2 What Drives the Stock Market Comovements between Korea and China, Japan and the US?

3 Who Improves or Worsens Liquidity in the Korean Treasury Bond Market?

4 Establishment Size and Wage Inequality: The Roles of Performance Pay and Rent Sharing

5 가계대출 부도요인 및 금융업권별 금융취약성: 자영업 차주를 중심으로

6 직업훈련이 청년취업률 제고에 미치는 영향

송호신 · 허준영

이철희 $\cdot$ 이지은

윤경수 · 차재훈 - 박소희 강선영

한재준 · 소인환

Inhwan So

최영준

Youngju Kim • Hyunjoon Lim

이지홍·임현경·정대영

Jinsoo Lee

Bok-Keun Yu

Jieun Lee

Sang-yoon Song

정호성

최충 - 김남주 - 최광성 


\section{제2018-7 재고투자와 경기변동에 대한 동학적 분석 서병선-장근호}

8 Rare Disasters and Exchange Rates:

Cheolbeom Park

An Empirical Investigation of Korean

Suyeon Park

Exchange Rates under Tension

between the Two Koreas

9 통화정책과 기업 설비투자

- 자산가격경로와 대차대조표경로 분석 -

박상준 $\cdot$ 육승환

10 Upgrading Product Quality:

The Impact of Tariffs and Standards

Jihyun Eum

11 북한이탈주민의 신용행태에 관한 연구

정승호·민병기·김주원

12 Uncertainty Shocks and Asymmetric Dynamics in Korea: A Nonlinear Approach

Kevin Larcher • Jaebeom Kim . Youngju Kim

13 북한경제의 대외개방에 따른 경제적 후생 변화 분석

14 Central Bank Reputation and Inflation-Unemployment Performance:

정혁·최창용·최지영 Empirical Evidence from an Executive Survey of 62 Countries

15 Reserve Accumulation and Bank Lending: Evidence from Korea

16 The Banks' Swansong: Banking and the Financial Markets under Asymmetric Information

17 E-money: Legal Restrictions Theory Ohik Kwon $\cdot$ Jaevin Park and Monetary Policy

18 글로벌 금융위기 전·후 외국인의 채권투자 결정요인 변화 분석: 한국의 사례

In Do Hwang

Youngjin Yun

Jungu Yang

$$
\begin{aligned}
& \text { 설비자본재 기술진보가 근로유형별 임금 김남주 } \\
& \text { 및 고용에 미치는 영향 }
\end{aligned}
$$




\begin{tabular}{|c|c|c|}
\hline 제2018-20 & $\begin{array}{l}\text { Fixed-Rate Loans and the } \\
\text { Effectiveness of Monetary Policy }\end{array}$ & Sung Ho Park \\
\hline 21 & $\begin{array}{l}\text { Leverage, Hand-to-Mouth Households, } \\
\text { and MPC Heterogeneity: Evidence from } \\
\text { Korea }\end{array}$ & Sang-yoon Song \\
\hline 22 & $\begin{array}{l}\text { 선진국 수입수요가 우리나라 수출에 } \\
\text { 미치는 영향 }\end{array}$ & 최문정·김경근 \\
\hline 23 & $\begin{array}{l}\text { Cross-Border Bank Flows through } \\
\text { Foreign Branches: Evidence from } \\
\text { Korea }\end{array}$ & Youngjin Yun \\
\hline 24 & $\begin{array}{l}\text { Accounting for the Sources of the } \\
\text { Recent Decline in Korea's Exports to } \\
\text { China }\end{array}$ & $\begin{array}{l}\text { Moon Jung Choi } \\
\text { Kei-Mu Yi }\end{array}$ \\
\hline 25 & $\begin{array}{l}\text { The Effects of Export Diversification on } \\
\text { Macroeconomic Stabilization: Evidence } \\
\text { from Korea }\end{array}$ & $\begin{array}{l}\text { Jinsoo Lee } \cdot \\
\text { Bok-Keun Yu }\end{array}$ \\
\hline 26 & $\begin{array}{l}\text { Identifying Uncertainty Shocks due to } \\
\text { Geopolitical Swings in Korea }\end{array}$ & $\begin{array}{l}\text { Seohyun Lee } \\
\text { Inhwan So } \\
\text { Jongrim Ha }\end{array}$ \\
\hline 27 & $\begin{array}{l}\text { Monetary Policy and Income Inequality } \\
\text { in Korea }\end{array}$ & Jongwook Park \\
\hline 28 & $\begin{array}{l}\text { How the Financial Market Can Dampen } \\
\text { the Effects of Commodity Price Shocks }\end{array}$ & Myunghyun Kim \\
\hline 29 & $\begin{array}{l}\text { Which External Shock Matters in Small } \\
\text { Open Economies? US Economic Policy } \\
\text { Uncertainty vs. Global Risk Aversion }\end{array}$ & $\begin{array}{l}\text { Youngju Kim } \cdot \\
\text { Hyunjoon Lim }\end{array}$ \\
\hline 30 & $\begin{array}{l}\text { Do Korean Exports Have Different } \\
\text { Patterns over Different Regimes?: } \\
\text { New Evidence from STAR-VECM }\end{array}$ & $\begin{array}{l}\text { Sei-Wan Kim } \cdot \\
\text { Moon Jung Choi }\end{array}$ \\
\hline 31 & 기술진보와 청년고용 & 심명규·양희승·이서현 \\
\hline 32 & $\begin{array}{l}\text { 북한지역 장기주택수요 및 연관 } \\
\text { 주택건설투자 추정 }\end{array}$ & 이주영 \\
\hline 33 & 기업규모간 임금격차 원인 분석 & 송상윤 \\
\hline
\end{tabular}




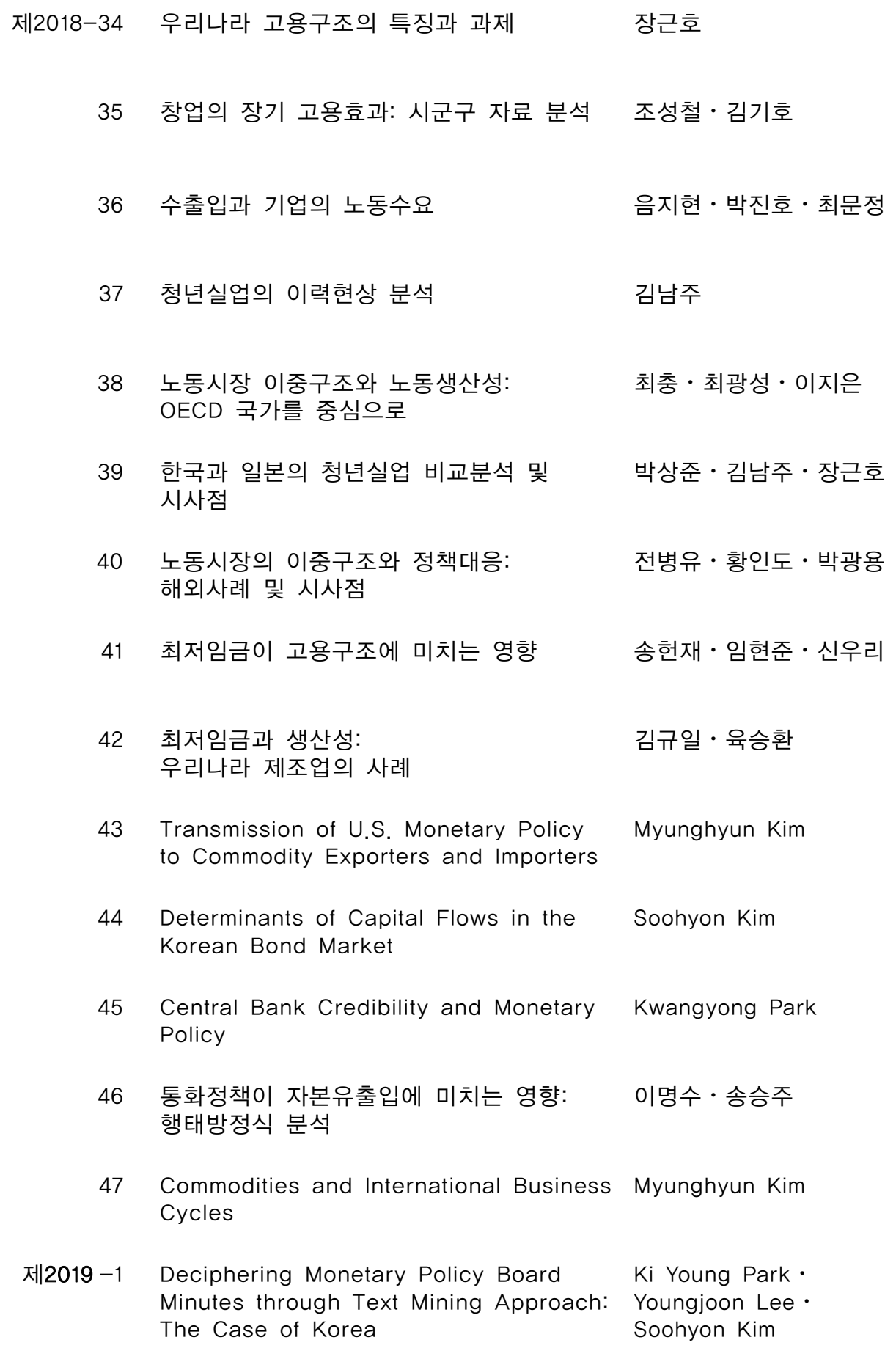


제2019-2 The Impacts of Macroeconomic News Announcements on Intraday Implied Volatility

3 Taking a Bigger Slice of the Global Value Chain Pie: An Industry-level Analysis

4 Trend Growth Shocks and Asset Prices

5 Uncertainty, Attention Allocation and Monetary Policy Asymmetry

6 Central Bank Digital Currency and Financial Stability

7 은행의 수익 및 자산구조를 반영한 통화정책 위험선호경로

8 혁신기업에 대한 산업금융 지원: 이론모형 분석

9 가계부채 제약하의 통화정책: 2주체 거시모형(TANK)에서의 정량적 분석

10 Alchemy of Financial Innovation: Securitization, Liquidity and Optimal Monetary Policy

11 Measuring Monetary Policy Surprises Using Text Mining: The Case of Korea

12 Tracking Uncertainty through the Relative Sentiment Shift Series

13 Intra-firm and Arm' s Length Trade during the Global Financial Crisis: Evidence from Korean Manufacturing Firms

14 특허자료를 이용한 우리나라 지식전파의 지역화 분석

15 Overhead Labour and Skill-Biased Technological Change: The Role of Product Diversification
Jieun Lee .

Doojin Ryu

Chong-Sup Kim • Seungho Lee . Jihyun Eum

Nam Gang Lee

Kwangyong Park

Young Sik Kim •

Ohik Kwon

김의진 · 정호성

강경훈 - 양준구

정용승 - 송승주

Jungu Yang

Youngjoon Lee

Soohyon Kim •

Ki Young Park

Seohyun Lee

Rickard Nyman

Moon Jung Choi Ji Hyun Eum

이지홍 - 남윤미

Choong Hyun Nam 
16

Does the Number of Countries in an International Business Cycle Model

Matter?

17 High-Frequency Credit Spread Information and Macroeconomic Forecast Revision

18 경제 분석을 위한 텍스트 마이닝

19 Takeover, Distress, and Equity Issuance: Evidence from Korea

20 The Cash-Flow Channel of Monetary Policy: Evidence from Mortgage Borrowers

21 부의 효과의 분위 추정: 분위 정준 공적분회귀를 중심으로

22 Identifying Government Spending Shocks and Multipliers in Korea

23 Systemic Risk of the Consumer Credit Network across Financial Institutions

24 Impact of Chinese Renminbi on Korean Exports: Does Quality Matter?

25 Uncertainty, Credit and Investment: Evidence from Firm-Bank Matched Data

26 A Structural Change in the Trend and Cycle in Korea

제2020-1 인구 고령화가 실질 금리에 미치는 영향

2 달러라이제이션이 확산된 북한경제에서 보유외화 감소가 물가 - 환율에 미치는 영향

3 상태공간 벡터오차수정모형을 이용한 월별 $\mathrm{GDP}$ 추정: 깁스표본추출 접근

4 우리나라 외환시장 오퍼레이션의 행태 및 환율변동성 완화 효과
Myunghyun Kim

Bruno Deschamps · Christos loannidis . Kook Ka

김수현 - 이영준 - 신진영 · 박기영

Euna Cho

Sang-yoon Song

김기호

Kwangyong Park ·

Eun Kyung Lee

Hyun Hak Kim •

Hosung Jung

Jihyun Eum

Youngju Kim •

Seohyun Lee .

Hyunjoon Lim

Nam Gang Lee

Byoung Hoon Seok

권오익·김명현

문성민·김병기

김기호

박준서·최경욱 
5 Common Factor Augmented Forecasting

Hyeongwoo Kim •

Models for the US Dollar-Korean Won

Soohyon Kim

Exchange Rate

6 북한 「경제연구」로 분석한 경제정책 변화: 김수현·손 욱 텍스트 마이닝 접근법

7 북한의 광물 수출과 품목별 수입: 대중무역을 김병연 - 김민정 - 김다울 중심으로

8 Network-Based Measures of Systemic Risk in Korea

Jaewon Choi

Jieun Lee 